control group, and especially in alloxan and dithizon injected group, permanent diabetes occured in the highest degree.

2. a) The inhibition to the growth of cultured tissues was most manifest in the serum of alloxan injected group, dithizon next, and in the serum of oxin injected group and depancreaticomized diabetic dogs, growth inhibitions were more or less slighter.

b) In each group, the growth inhibition was severest at the initial hyperglycemic phase and at the second hypoglycemic phase. At the early period of the permanent hyperglycemic phase, tissue injuries were slightest, and later the injuries became more manifest again.

c) Among the tissues of chick-embryo, liver was most sensitive to tha additioned blood-sera of experimental diabetic animals and always exhibited growth inhibition of various severity.

3. When the sera of the experimental diabetic animals inactivated by the heat or filtered by the chamberand filter and or absorbed by caorin, its controllable power were relatively reduced. This, remarkable at the inactivated serum by the heat, but nicht so remarkable at the serum filtered or absorbed.

4. No correlation was found between the severity of the tissue injuries and blood sugar levels of these experimental diabetic animals. Then, as the late Prof. Iisuka discussed, the diabetogenic "toxin" shall exist nicht related to hyperglycemia.

\title{
Pregnanediol in Urine and its Significance in Obstetrics and Gynecology
}

\author{
By \\ Yoshiyuki NAKTA \\ Department of Obstetrics and Gynecology, School of Medicine, Tokushima University.
}

(Director : Prof. Dr. Muni Iida)

The present work, as a part of Prof. Iida's study on the sterilization by forming corpus luteum artificially, has been done to estimate the astion of trophoblast hormone (T.B.H.) in relation to its luteinizing and luteotrophic effect.

In Part I of this report, the author examined critically the procedures of the quantitative determination of pregnanediol (PG) in urine. In his own work the author adopted with some modification the chromatographic methos of Watteville for extraction and purification of PG in urine and the sulphuric acid method of Guterman with spectrophotometry for its microdetermination. The sulphuric acid method is said to be the most accurate for microdetermination of $\mathrm{PG}$, but it is not the characteristic reaction for PG alone, so the best attention was payed to extraction of PG from urine and its purification. Thus the author succeeded in isolating two samples of crystal with sublimating property from the urine of a pregnant woman. One of them was ketonic (pregnanedion) and the other nonketonic (PG). Melting points and the result of the organic microanalysis were satisfactorily coincident with the theoretical values for each of them. Making use of this crystal in the sulphuric acid method of Guterman, the relation between the spectral absorption at $420 \mathrm{~m} \mu$ and the quantity (mg) of PG, i.e. the standard curve for the spectrophotometric microdetermination of PG, was decided by means of Beckman's spectrophotometer (type DU). The recovering test and some other tests confirmed the

Voll. 32 No. 12 
accuracy and the reliability of the method above-described for microdetermination of PG in urine. The author believes that this method may be used for clinical purposes.

In Part II of this report, the author tried to ascertain how the amount of PG in urine varies with the menstruation, the conception and related disorders or diseases. He also tried to elucidate the relation of PG in urine to T.B.H. administration, hypophyseal and suprarenal functions. The results were summarized as follows.

1) In the normal menstrual cycle, $\mathrm{PG}$ appeared in urine only at the luteal phase and its appearance was less marked in the disorderly menstrual cycle. The time of ovulation may be more easily inferable by the appearance of PG in urine than by other methods now in use. When the periods were changed artificially by administration of T.B.H., PG appeared a little earlier, if administered at the early estrogenic phase, but the T.B.H. administration at the luteal phase cause 1 the elongation of the luteal phase, accompanied by a significant increase in PG excretion.

2) PG in urine reflected truly the ovarian function, particularly the corpus luteum activity, also in the irregular menstrual cycle. The unovulatory cycle were ascertained by PG determination in urine better than by endometrial examination or by B.B.T. test. It was also assured that T.B.H. administration served better in the cure of the irregular menstrual cyle or of the functional sterility than any other hormone therapy, from the view-point of the PG increase in urine.

3) In the earlier stages of the normal conception PG in urine did not show any marked increase as compared with that in the luteal phase, but after the 16 th week it remarkably increased and reached its maximum at the 32nd week, which continued till parturition. After parturition PG in urine suddenly decreased and disappeared 98 hours after delivery.

4) The amount of PG in urine was remarkably less in the toxemia of pregnancy as compared with that in the normal conception. This fact was coincident with the results of other clinical examinations. Thus it may be presumable that the toxemia of pregnancy is caused by the disorderly renewal of hormones, so the determination of PG in urine may serve as a factor in judging the prognosis of the toxemia.

5) By administration of T.B.H. for protection from the threatened abortion the amount of PG in urine increased, accompanied by the amelioration of symptoms. PG in urine is not only indicative of the effect of T.B.H., but its determination may serve in deciding the prognosis of the threatened abortion. In case of the threatened abortion the author performed the PG determination with 200cc urine with good results. It is customary that 24 hours urine is used for PG determination even in case of the threatened abortion, but it is absurd and inconvenient.

6) The determination of PG in urine had little value in the diagnosis of the ectopic pregnancy. In this case the 3 urine color test of Dr. Ashidaka may yield better results. In case of the dead foetus PG excretion in urine decreased as the function of placenta became weaker. So the determination of $P G$ in urine, if repeated at intervals, may serve in the diagnosis of the dead foetus.

7) In case of chorioepithelioma the amount of PG in urine was small, although no case was found in which PG did not appear in urine in spite of the positive value in Dr. Shirai's trophoblast test. Such low level of PG in urine may serve in the diagnosis of chorioepithelioma, if PG determination is combined with the Shirai's and the Ashidaka's test.

8) Progesterone, administered by intramuscular injection, was excreted as PG in urine during 48 hours. The amount of excretion was $14.6 \%$ at the luteal phase, $6.2 \%$ at the estrogenic phase and $6.9 \%$ in the 
castrated woman. It shows that the conversion of progesterone into PG and its excretion may vary with the functional state of the endocrine glands.

9) Only a slight difference was found in the time of appearance of PG in urine according as the progesterone was given by intravenous, intramuscular or oral administration, though no difference was found in the total amount of PG in urine.

10) No difference was remarkable in the amount of PG in urine according as the estrogen treatment was done or not before administration of progesterone to the castrated woman.

11) Administration of ACTH, cortisone acetate, T.B.H. or testostrone propionate to the castrated woman had no influence upon the amount of PG in urine, though the number of eosinophile leucocytes in blood or the amount of 17K.S. in urine was influenced.

\title{
Influence of Thyroid Hormone on the Release of Antidiuretic Hormone from Neurohypophysis.
}

\author{
By
}

Takashi UENO and Michie KUROKAWA

Institute of Physiology, School of Medicine, University of Nagoya.

The effect of the thyroid activity on the antidiuretic potency of blood serum and on the ADH content in neurohypophysis was studied in rats biologically and also by means of Gomori's alum-chromehematoxylin-phloxine staining.

In the thyroidectomized rats, 28 days after the operation, the $\mathrm{ADH}$ content in neurohypophysis and the blood ADS were slightly higher than normal levels.

In rats injected hypodermically with 0.05 or $0.5 \mathrm{ml}$ of Thyradin (corresponded to 10 or $100 \mathrm{mg}$ of desicated thyroid) per $100 \mathrm{~g}$ body weight daily for the periods of 12 or 28 days, ADH content and blood ADS were moderately lower than normal values.

In neither above mentioned cases, any significant cytological change in the posterior pituitary gland and in neurosecretory nuclei of hypothalamus occured. 


\section{産婦人科領域に於ける尿中 Pregnanediol \\ 排 泄量‧とその意 義}

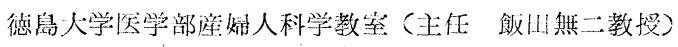

H田善它

本論文の要旨は第 8 回日本産科婦人科学会総会(昭和 31 年 4 月，東京）第 $7 ， 8$ 回日本産科㛿人科学会中

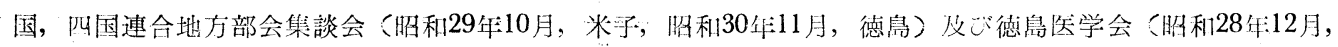
昭和29尔 6 月，比和30年 2 月，昭和30年 7 月，德息:に於て発衣した。

\section{目}

前 篇 基整奏験

第 1 幛 緒

第 2 章 尿中 P.G. 测定法の概略

第 1 節 重量測定法

第 1 項 Venning, Browne 法

第 2 项 Astwood, Jones 法

第 2 節 点滴测定法

第 3 節 沈降試験法

第 4 節 Chromatography 測定法:

第 5 節 比色测定法

第 3 章 実験立泣考按

第 1 節 実験方法

第 1 項 武 薬

第 2 項 使用器具

第 3 項 実験操作

第 2 節 実験成績立位考按

第 1 項 採尿時に於ける P.G. の損失

第 2 項 不純物の除去立に濃縮法

第 3 項 Ghromatography についた

第 4 項 呈色反応について

第 5 項 回収武験

第 4 章 結 辞

\section{後 篇 臨床実験}

第 1 章 緒 乼

第 2 章 月経湖期と尿中 P.G. 排淮最及でこ 札凄.B.H.乞心開係

第 1 節 正:常月経周期之永中P.(. .

第 1 項 実験目的

第 2 項 実験方法

第 3 项 买験成縝
次

第 4 项 考 按

第 2 節 異常月経周期と尿中 P.G.

第 1 項 実験目的

第 2 項 契験方法

第 3 項 実験成䋶

第 4 項 考 按

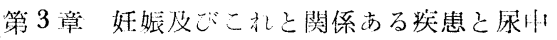

P.G. 排泄量

第 1 節 正常弤:娠, 分娩, 産褯時の尿中P.G.

第 1 項，笑験及びこひ成結

第 2 項 考 按

第 2 節”妊娠中毒症時U尿中 P.G.

第 1 項 実験及びその成綨

第 2 項 考 按

第 3 節 流早産時の尿中 P.G.

第 1 項 実験及びその成績

第 2 項 考 按

第 4 節 子葟外妊娠立立に死胎㭙の尿中 P.

$\mathrm{G}$.

第 1 项 实駼及びその成縝

第 2 項考 按

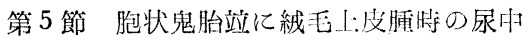

$$
\text { P.G. }
$$

第 1 項 実験及びその成繥

第 2 項 考 按

第４章補尤些呀

第 1 簛 第駼团的

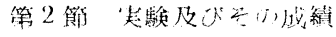

第 3 節 考 按

第 5 章 全篇の総括站飞結論

$$
\text { 文献 }
$$


前篇 基 礎 実験

\section{第1章 緒}

言

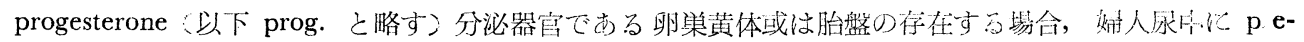

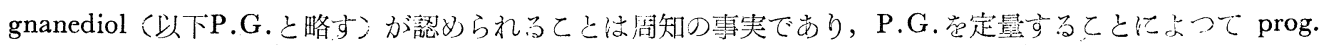
の産生並びて体内変化を推測するととが出来马。

近年性ホルモンの研究が著しく発展したのは，血腹中义は尿中に於けるそのホルモン量觉測定すのことに 上るといつても渦言ではある案い，従来 steroid hormone の中 prog. が estregen や androgen 等に比し

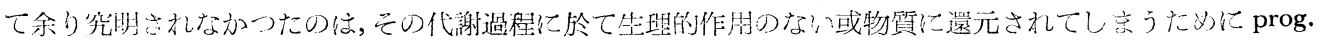

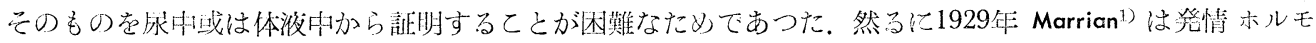

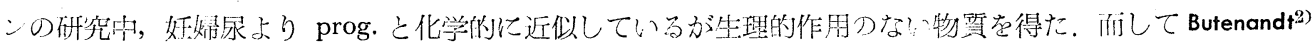
(1930)はこれか䚾娠と密接な関係を有するととから P.G. と命名し，ての構造式を決定した．P.G.とは

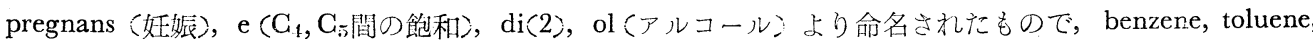
alcohol, chloroform 等汇は容易汇溶解するが ether には難容, 水には不溶である。毛徐本物質は Butenandt 及び Schmidt3) (1934) により八ロゲンを触媒として prog. 亿酸化し得ること，Venning 及び Browne')

Fig. 1 Sodium pregnanediol glucuronidate

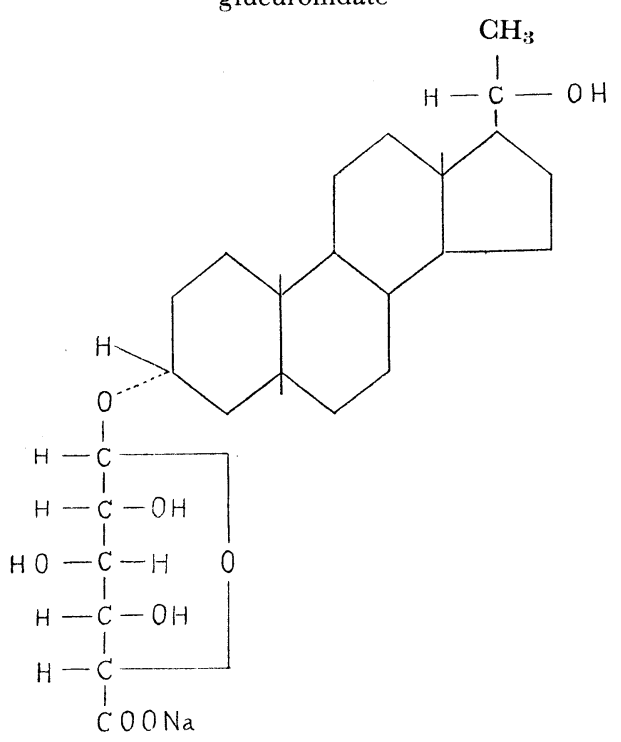

(1936) 等の研究により prog. の終末代㓔産物として 生物学的に不活性な sodium P.G. glucuronidate(Fig.1) として尿中に排湖されるものであることが判明し，重 量法による測定法が発表され，1937年には非姖邚承け 亿も月経周期の黄体期に一致して，乙れつ諗》られる こと苍報告するに至つて, prog. は体内で $\Delta^{\mathrm{t}-3 \mathrm{ketone}}$

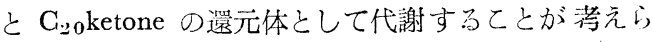
れ，prog. 代謝力研究は尿中P.G. 存測定学乃ととに上 つて間接的ではあるが比較的容易に行い得るようにな つた.

以来我国に於てもとの種の研究は急速に盛となり, 既亿幾多の報告がなされているが，現在尚 P.G.の意 義に関する研究も未だ完成の域に達せず，その測定法 も日進月歩着々と改良されている状態で P.G. 発見当 特諸家の沜に抱かれた期待は未だ極く一部分しか達成 されていない．乙れには Plotz文等の云う则くそその 研究途上 desoxycorticosterone 等の如き他入 steroid hormone P.G.として排泄されることが判明し，研 究結果堂混迷させたととき一因となつていると思われ

るが，この成績を充分に吟味検討するならば，永中P.G.の測定は生体に於ける prog. 産生状沅䁈見する ための貴重な手段であり， prog. 亿関する諸研究すこの種の研究てよつて益々発展するものと予想される。

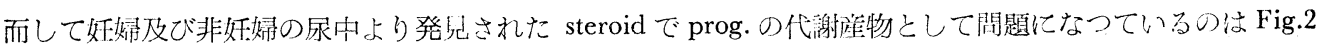

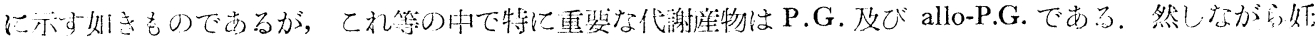

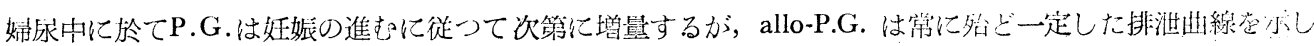
て打り (Tompsett ${ }^{6)}$ 1949)，乙れ等以外の $\mathrm{C}_{21}$ steroid はすべて prog. 分泌の盛な妊娠期間中に於てのみ見ら れるものであるとされている。

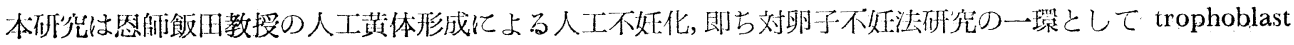


Fig. 2 Metabolic products of Progesterone in urine of pregnant and non pregnant women
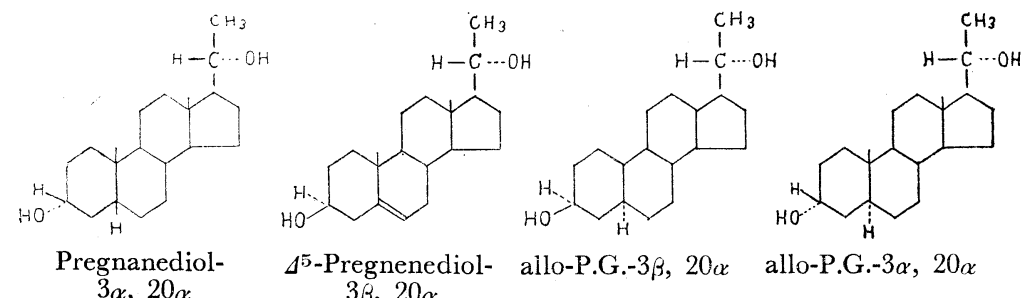

$\Delta^{5}$-Pregnenediol-
$3 \beta, 20 \alpha$

allo-P.G.- $3 \alpha, 20 \alpha$<smiles>CC(=O)C1CCC2C1CCC1C3CC[C@H](O)CC3CCC12</smiles>

Pregnanol$3 \alpha$, on- 20<smiles>CC(=O)C1CCC2C1CCC1C2CC[C@@H]2CC(O)CCC12</smiles>

allo-Pregnanol$3 \beta$, on -20

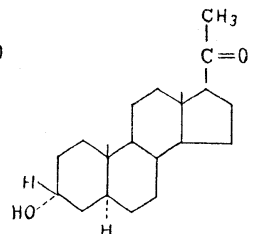

allo-Pregnanol$3 \alpha$, on -20<smiles>CC(=O)C1CCC2C1CCC1C3CCC(=O)CC3CCC12</smiles>

Pregnanedion3,20<smiles>CC(=O)C1CCC2C1CCC1C3CCC(=O)CC3CCC12</smiles>

allo-Pregnanedion3, 20

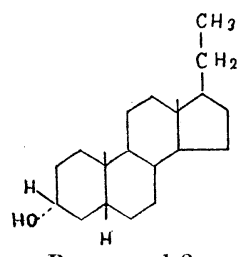

Pregnanol- $3 x$

hormone (以下T.B.H.と略す)の諸作用の中，特に luteinizing effect 並びに luteotrophic effect を究眀するるために始㠺たもので，先づ尿中P.G．の定量法を 確立し，乙れが産婦人科領域に於ける臨木的価值について検討すると共に, prog. の体内産生場所及びその還元㙨序党追求し，更に T.B.H. がこれらに刘して如何 なる影響を及将すか，又とれと他のホルモンとの関係は如何を知る棠目的とした ものである。

\section{第 2章 尿中P.G. 測定法の概略}

prog. は生物学的に Corner 法 (1928) 及び Clauberg 法 (1930), 或は微量定量法としての HookerForbes 法 (1947) によつて測定されるが藤井7) 等は testosterone, desoxycorticosterone, diethylstilbestrol 等も用量が多ければ Hooker-Forbes 反応も陽性となるといつている。乙れに反しP.G.注尃ら化学的て測定 されろが，尿中よりP.G・量を測定したのは Venning 及び Browne が sodium P.G. glucuronidate (以下 s.P.G.g. と略す)を buthanol で抽出して，との重量を测つたのが最初である。，以来幾多つ方法が報告され ているが，乙れを大別すれば次の 2 群となる。

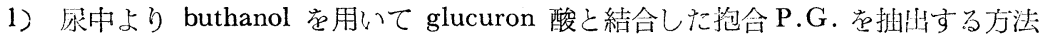

2) 尿を加水分解して遊離P.G. 芷 toluene にて抽出する方法

\section{第 1 節 重量測定法}

第 1 項 Venning，Browne 法)，8）本法の特色はs.P.G.g. が buthanol そ極》てよく浴解し，文酸性，中 性,アルカリ性水溶液の何れからも抽出し得るという点にあるが, s.P.G.g.の分子式は $\mathrm{C}_{2}: \mathrm{H}_{43} \mathrm{O}_{8}-\mathrm{NaH}_{2} \mathrm{O}$ で あるから $32 \% 30=0.597$ を乗じてP.G.亿換算せねばならない. 又Westphal ${ }^{9)}$ 法は Na 部分を Baで嗅換して， 水に不溶な化合物となして沈澱せしめるのである。然しながら何れにせよ最初から尿中に遊離して存任する

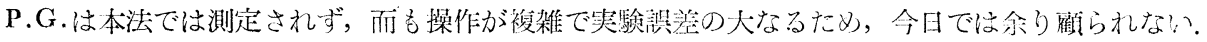

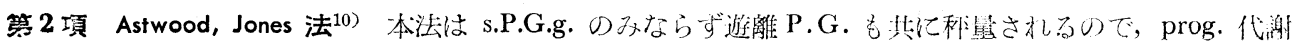
の研究には比較的正確な方法として，大!、注目せられ検討された.然しながら各段湝に於て少からずP.G. の損失を招き，実験の統訢的観察加ら Astwood は科量 P.G.值 $(\mathrm{mg}) \times(24$ 時間全㽷量/被検尿量 $) \times 1.47=$

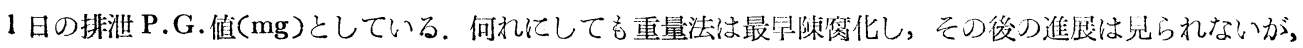


各種の測定法はすべてての重量法の途中段階むでの操作を基として案出されたもので，頗る意義の深いもの， である.

\section{第 2 節 点滴測定法}

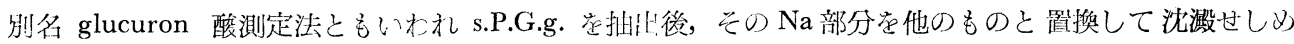
てから加水分解し，遊離した glucuron 酸苞種々の方法で測定するもので Allen 法 ${ }^{11)}$ (1941) 及び意義が多 少異るが松田 ${ }^{12)}$ (1953) の变法がある。

\section{策 3 節 沈隆試験法}

Mack，Parks ${ }^{13)}$ (1947) により報告されたもので，Astwood, Jones 法に於て toluene 抽出物を乾固し，残 湢を acetone にて溶解して後, 温 $0.1 \mathrm{~N} \mathrm{NaOH} 25 \mathrm{cc}$ 加えてP.G. を沈澱せしめる. 而して泠却後, 沈澱 物或は沈降物の状態を Kahn の視察器を用いて判定するP.G. 定性法であるが，同時に定量も可能であると いつている.

\section{管 4 筑 chromatography 測定法}

Huber ${ }^{14)}$ (1947)，Watteville ${ }^{15)}$ (1948) 等は酸化アルミニウム学吸着剂とした Chromatography によつて 他の steroid 体上り P.G. 老純䊉に分離し得るととを発表し，0.2 0.8mgの微量をも測定し得るといつてい

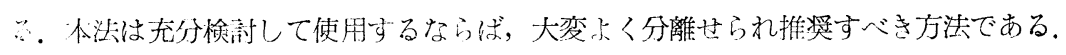

\section{館 5 節 比色測定法}

Talbof ${ }^{16)}$ (1941), Guterman ${ }^{17}$ ) (1948), Semmons ${ }^{18}$ (1949), Smith ${ }^{19)}$ (1950) 等は Astwood, Jones 法の最

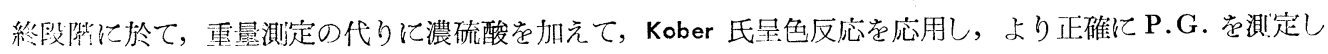
得ると発表した。 今日同法に些少の改良蛋加えた方法が最も公く応用されているが，てれは現在同法が最も 碓実な測定法であり，就中微量定量法としては聮比なものであるという特性によるのであろう．然しながら この硫酸による是色は極めて鋭敏であるが，Zimmermann 等によりP.G.のるに特異な反応てないてとが明 ふッされたために，その抽仙，精製，純化の諸段階が充分检討されねね゙ならない。

\section{第3 章 実験竝びに考按}

\section{第 1 節 実験方法}

Guterman 法17) U Watteville ${ }^{15)} の$ Chromatography 採用し，乙れに若干の改良を加えて実験法とした。 更にてれを基集として松田変法 ${ }^{12)} も 一$ 部併用し, 比較検討した。

第 1 項 試薬（1精製トルエン (2濃塩酸 (3) $2 \mathrm{~N} \mathrm{NaOH} 20 \% \mathrm{NaCl}$ 溶液 (4) $2 \%$ 苛性ソーダメタノール 溶液 (5)クロマトグラフ用活性アルミナ (6)精製ベンゼン (7)ベンゼンメタノール溶液 (95: 5) (8)精製エタ) ール (9)濃硫酸(特級).

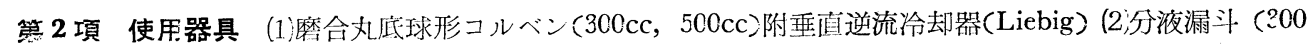
cc，500cc）(3)平底コルベン(200cc)(4)減庄蒸溜装置並びにトルエン回収装置(Fig.3) (5) fritted glass filter (medium porosity pyrex G3) (6)滤過瓶(200cc) (7)カラムクロマトグラフ装置(Fig.4) (8)磨合蓋付三角コル ベン (40cc，100cc) (9)島津製 Beckman Spectrophotometer DU 型.

篹 3 項 実験操作 toluene を数滴々下して採集せる24時間尿を濾過し, その $100 \mathrm{cc}$ (場合により $200 \mathrm{c}$ 》赏

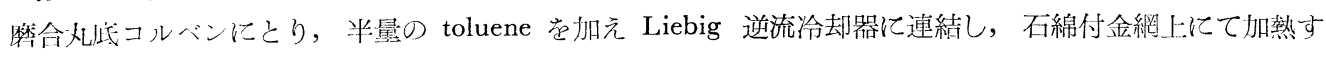

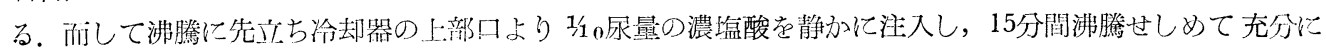

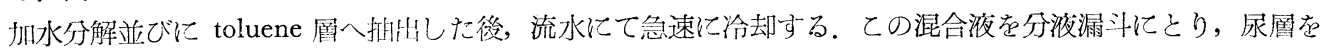
分離し, 更に別の分液漏斗空用いて $25 \mathrm{cc} の$ toluene にて $2 \sim 3$ 回再抽出する. てれらを 1 個の分液漏斗に

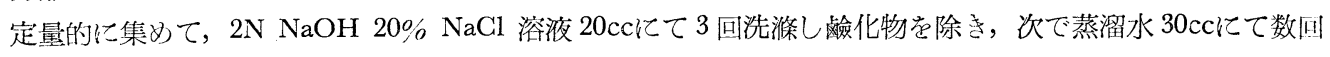
洗滌する.かつ操作により透明な赤紫色の toluene 抽出液を得る。

次で該抽出液を平底コルベンに定量的に移して hot-plate 上に暫時放置するか, 或は完全に乾燥せる他刀 コルベンに移すかして，水分を完全に除去して後，2\% NaOH-methanol 溶液10 ccを加え減王蒸溜装置を附 
Fig. 3 Apparatus for distillation under reduced pressure and for recovery of toluene

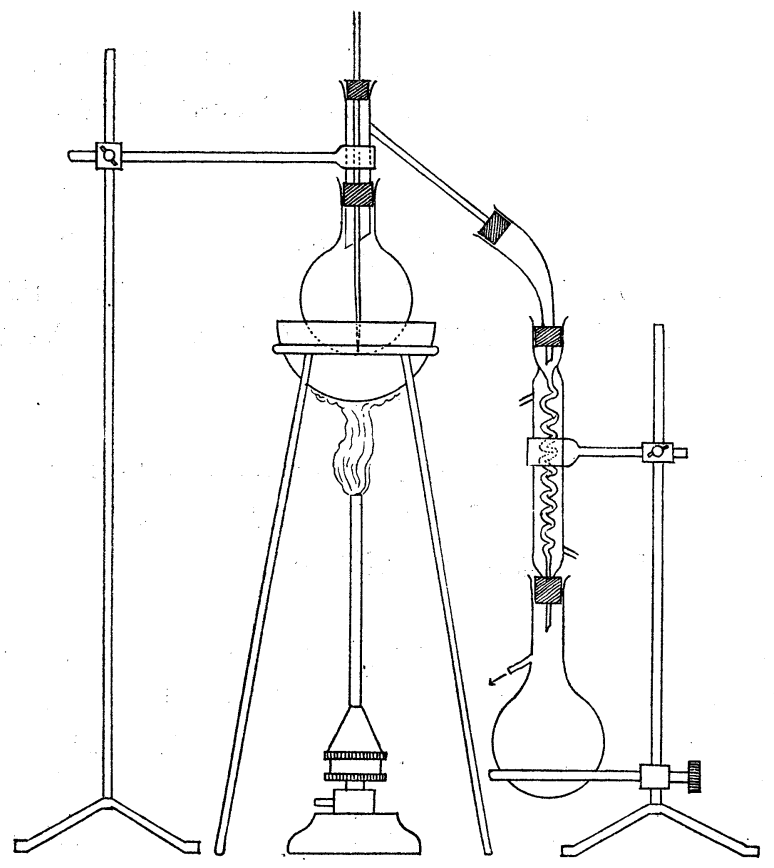

Fig. 4 Apparatus for

Chromatography

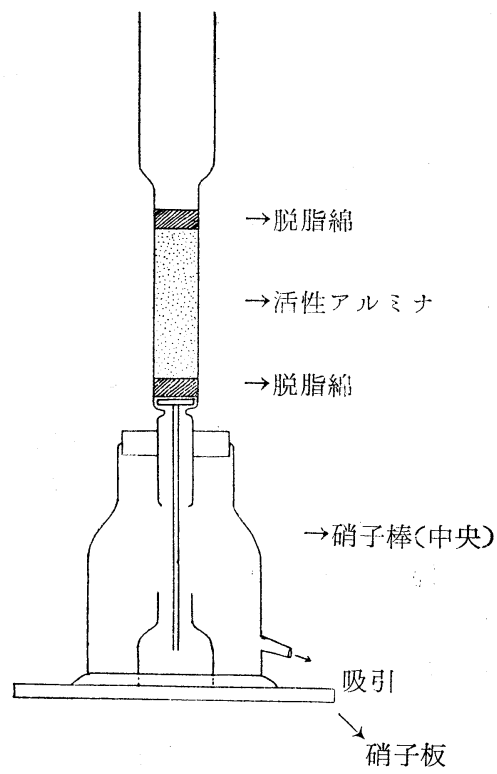

して toluene を回収しつ〉 water bathにて加熱し，不純物を沈澱せしめると共に大約13量にまで濃縮する。 放冷後, 該液を fritted glass filter にて弱く吸引!濾過し，残渣を少量の温 toluene にて洗い，定量的に滤淮 を聚集する。乙の際濾液は黄色乃至黄緑色を呈する。該滤液を減压下にて出来るだけ加熱を避けつ〉10〜15 ccとなるまて蒸発せしめ，乙れを Chromatography にかけてP.G.を分離抽出する.

[クロマトグラフ法] 吸着管の底に脱脂綿を充填した後, 吸着用活性アルミナ約 $0.5 \mathrm{~g}$ 人れて benzene を 加え，その中に活性アルミナ(全量 $5 \mathrm{~g}$ )を沈下せしもて，空気の入らぬよう注意しつ〉均等に充媜し，最後 に再び脱脂綿を充填する。但し benzene はその表面以上にあるようにする.

次に前記操作にて得た toluene 抽出液を加えて弱く吸引しつ〉 P.G. を吸着柱に吸着せしめる. 然る後

Fig. 5

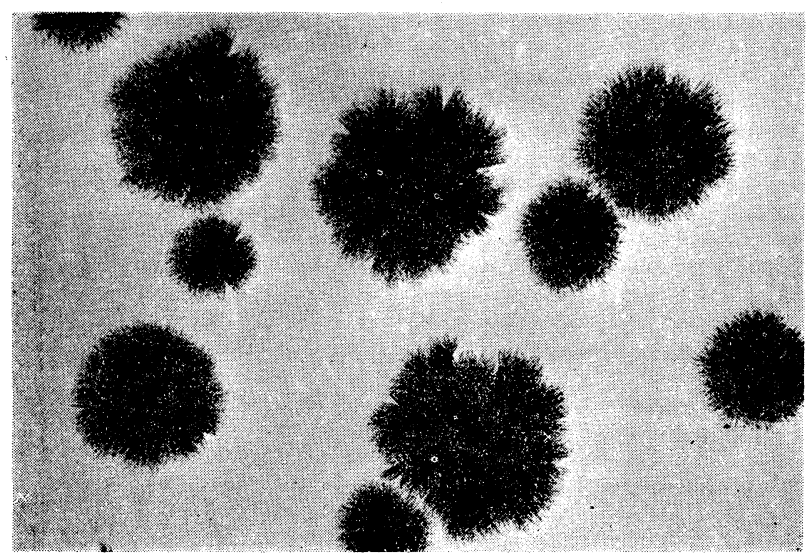

benzene $20 \mathrm{cc}$ にて展開し，次で benzene-methanol 溶液 $30 \mathrm{cck \tau}$ 磨 合蓝付コルベン中に elute $U$, 該液 尼減王下にて加熱甞避けつ〉蒸発乾 固せしもる.との residue 95\% alcohol 亿て溶解し, 90 100 ${ }^{\circ} \mathrm{C} の$ 蒸溜水 $50 \mathrm{cc}$ を加えて, 密栓下に て冷蔵庫に入れる。而して晶出せる P.G.を fritted glass filter そて集め, $30 \mathrm{cc} の$ 加温 $95 \%$ alcohol にて磨合蓋 付コルベン中に elute し, 減王下に て蒸発乾固せしめると，P.G.の日 色結晶が得られる。乙れを濃硫酸10 ccにて70分間呈色せしめた检, 
Fig. 6

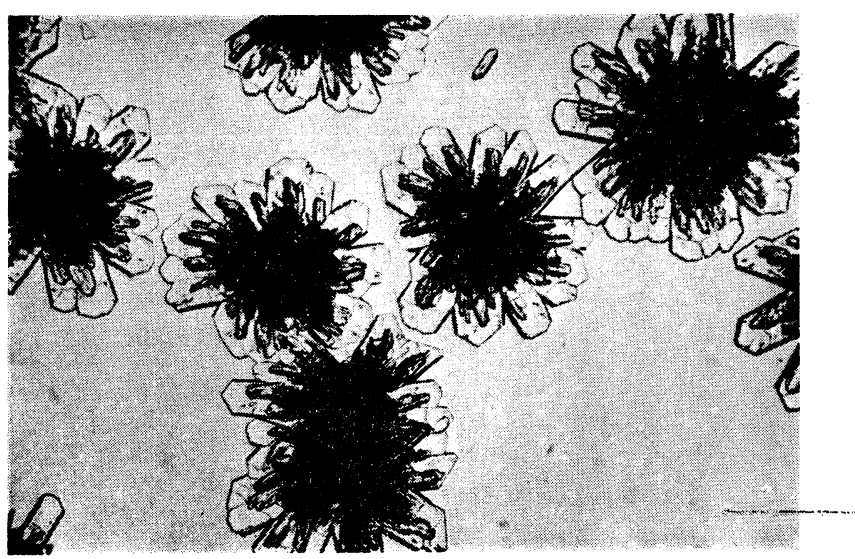

spectrophotometer を用いで $420 \mathrm{~m} \mu$ 波長にて濃硫酸奇刘照として比色定 量する。

\section{第 2 節 実験式績並びに考按}

前述の測定法を检討すると共に, 比色定異化必要な standard curve

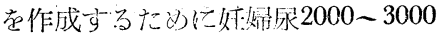

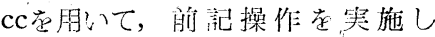
Chromatography 飞於て elute 迈 物質を 2 種に分離するとと觉得た。 而き共渒華性を有すると女を発自 し，てれらを純粋に昇華晶出せしぬ ると，前者はFig. 5 亿示守如䣄

Table 1. Organic elementary microanalyses

\begin{tabular}{|c|c|c|c|c|c|}
\hline 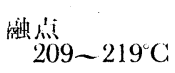 & $\begin{array}{l}\text { 鵤料 } \\
\quad 3.478 \mathrm{mg}\end{array}$ & $\begin{array}{l}\mathrm{H}_{2} \mathrm{O} \\
\quad 3.298 \mathrm{mg}\end{array}$ & $\begin{array}{l}\mathrm{CO}_{2} \\
\quad 10.093 \mathrm{mg}\end{array}$ & ${ }^{\mathrm{H}} 10.61 \%$ & $\mathrm{C}_{79.14 \%}$ \\
\hline 融点 $228^{\circ} \mathrm{C}$ & $\begin{array}{l}\text { 部料 } \\
\quad 3.466 \mathrm{mg}\end{array}$ & $\begin{array}{l}\mathrm{H}_{2} \mathrm{O} \\
\quad 3.438 \mathrm{mg}\end{array}$ & $\begin{array}{l}\mathrm{OO}_{2} \\
9.968 \mathrm{mg}\end{array}$ & ${ }^{\mathrm{H}} 11.08 \%$ & $\mathrm{C}_{78.43 \%}$ \\
\hline
\end{tabular}

Theoretical amount

\begin{tabular}{|c|c|c|c|}
\hline Pregnanedion & $\begin{array}{l}\text { 分子式 } \\
\mathrm{C}_{21} \mathrm{H}_{22} \mathrm{O}_{2}\end{array}$ & $\mathrm{H}_{10.19 \%}$ & C $79.68 \%$ \\
\hline Pregnanediol & $\begin{array}{l}\text { 分子式 } \\
\mathrm{C}_{21} \mathrm{H}_{36} \mathrm{O} .\end{array}$ & ${ }^{\mathrm{H}} 11.32 \%$ & ${ }^{\mathrm{C}} \mathrm{C} 78.68 \%$ \\
\hline
\end{tabular}

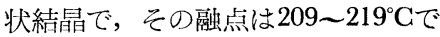
Zimmermann 法够により ketonic な るととが窺われ，後者は Fig. 6 の则 き結晶で $228^{\circ} \mathrm{C} の$ 融点を有し， meta-dinitrobenzene では着色せず, non-ketonic なるととが想像される。
Table 2. The loss of P.G. in collection of urine (dropped toluene in winter)

\begin{tabular}{|c|c|c|}
\hline $\begin{array}{ll}\text { 䝶 }^{-} & \text {蔵 } \\
& \text { 数 } \\
\end{array}$ & $\begin{array}{l}\text { 含. 有 } \\
\text { P. G. 量 }\end{array}$ & $\begin{array}{l}\text { 損分失 } \\
\end{array}$ \\
\hline 0 & $9.4 \mathrm{mg}$ & \\
\hline 1 & $9.1 \mathrm{mg}$ & $3.2 \%$ \\
\hline 2 & $8.6 \mathrm{mg}$ & $8.7 \%$ \\
\hline 4 & $7.4 \mathrm{mg}$ & $21.3 \%$ \\
\hline 6 & $6.9 \mathrm{mg}$ & $26.6 \%$ \\
\hline 8 & $5.6 \mathrm{mg}$ & $40.4 \%$ \\
\hline
\end{tabular}

侕して共に steroid の一般反応としての Liebermann-Buchard ${ }^{21)}$ 反 応は陽性を呈するも，共䡉二重結合を有する sterine に特有とさ れる Rosenheim ${ }^{22)}$ 反応は陰性であつた，又雨者の有機微量元素分 析を施行して前者点 pregnanedion の，そして後者をP.G.の理 論值と比較すると Tab. 1 亿示す如くで，所謂P.G.の結奛とし ては充分満足し得ると思われる。 そこでてれ学用いて次の如き检 討を試みた。

策 1 項 採尿時に於けるP.G.の損失 尿中 P.G.の排泄量は尿 量により，又個人によつても容易に変動し，同一人に於ても時闌 的に決して均一でない，從つて 1 日のP.G. 量は是非共24咕間篦 尿荧用いて測定すべきであつて，決して単位晊間内の測定値より

帰納してはならない。而も蓄尿する場合は㭙間と共に, 種々の変化や分解が起り, P.G. 量も刻々変化する

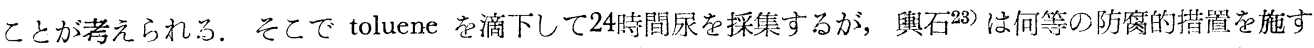
ことなく，奸婦尿 1 日量を 6 分し，時間的経過によるP.G.の損失を 2 日で $17.6 \% ， 6$ 日で $39.0 \%$ あつた といつている。余も亦実際的に toluene を滴下して採集した妊婦永 1 日量党 6 分し，更に夫々に toluene

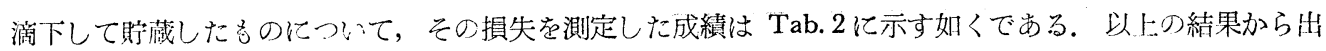
来る限り新鮮丞を使用ず゙きであり，又 toluene を滴下して採集すべきである. 
第 2 項 不純物の除去並びに濃缩法 分液漏斗より赤紫色の toluene 抽出液を平底コルベンに移してそ の中の水分を除去する場合，2－3個の乾燥せるコルベンに移すか，或は hot-plate 上に放置すべきであつ て電熱器等で直接加熱してはならない，又2\% NaOH-methanol 溶液を加えて濃縮する場命飞も，戦飞沸

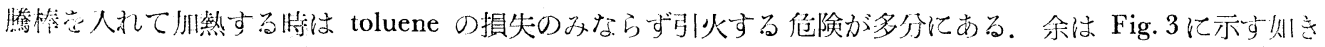

Fig. 7 Relation of extinction of P.G. (500 micrograms) to the time after reaction (Wave length $420 \mathrm{~m} \mu$ )

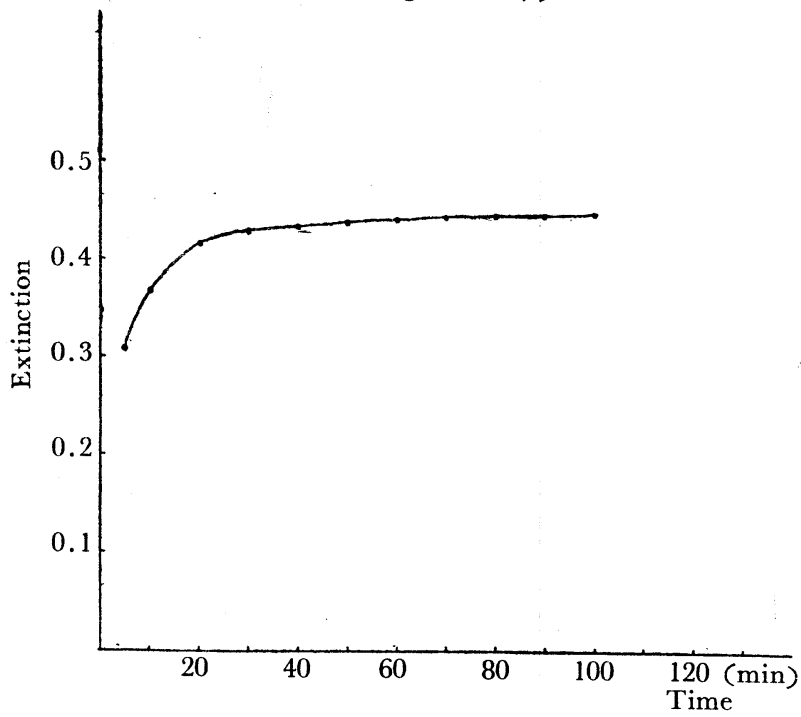

Fig. 8 Spectral absorpsion curve of sulfuric acid color test of P.G.

(500micrograms)

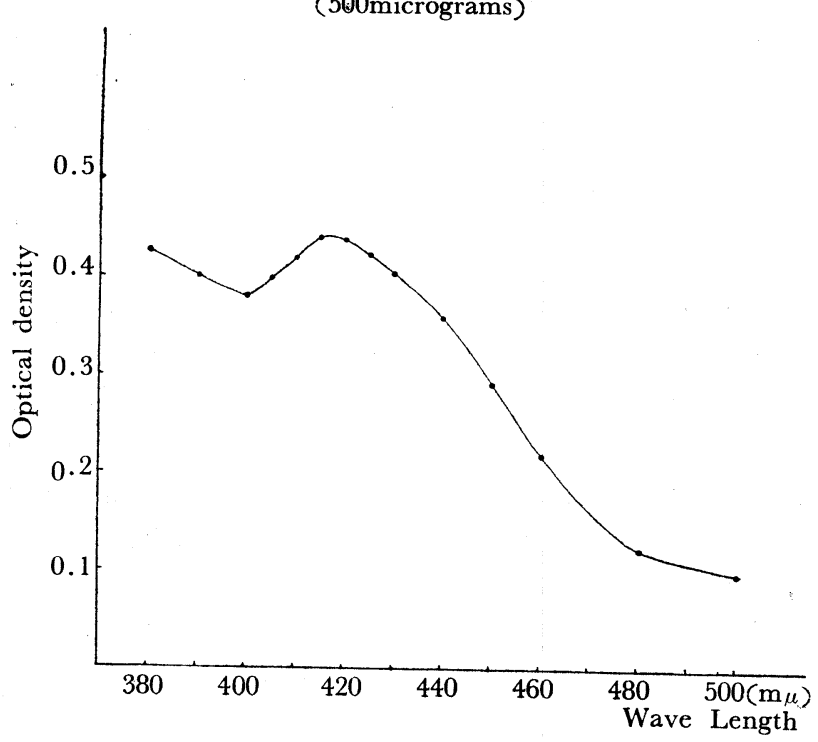

装犆を用いて water-bath 上にて行 い，安全に且つ濃縮時間も余程知縮 するとと存得た。

第 3 項 chromatography につ.で この場合充填より elution に至:岕 で，吸着首に空気を含ま扐う注意 すべきであり, 又液の流出速度が問 題となる。こてで活性アルミナの benzene 中心の自然沈下存利成する ならは古分淦足し得る。文濾液等 10 〜15cc志で蒸発せしめて chromatography にかけるのと, 乾固せし ひた垎 $0.5 \mathrm{cc} の$ methanol に溶解し, 更に 25ccの benzene 点加えて用い るのとでは大差なく, 寧乃前者の方 が時間的にも，又成績もよいことを 知つた. 次に活性アルミナの使用量 や benzene と methanol との混合 比並びに elute 量等について種々檢 詩した結果，前記 chromatography の略々完全であることを認めた。を こ の成績の一部は回収試験の項に於て 示す.

第4 項 呈色反応について 本法 は非常に鋭敏であるが，その難点は 或種の 17K.S.や Cholesterol 等にも 起り得ることである. 従つて抽出; 精製, 純化の過程が充分検討されね ばならないととは前述の如くこむる。 前記結昆を朋: てて行つた成績苞次に 示す.

(a) 反灾時間 結晶 $0.5 \mathrm{mg}$ 岩濃 硫酸 $10 \mathrm{cc}$ 亿て反応子しめ, $420 \mathrm{~m} \mu$ 波 長を用いて時間的に測定し，対数表 にて換算すると Fig. 7 亿示す则き curve が得られ70分で反応が略々完 了するととが窥える.

(b) spectral absorption curve そこで同条件で70分䦧反応せしめた 
Fig. 9 Standard curve for spectral absorpsion

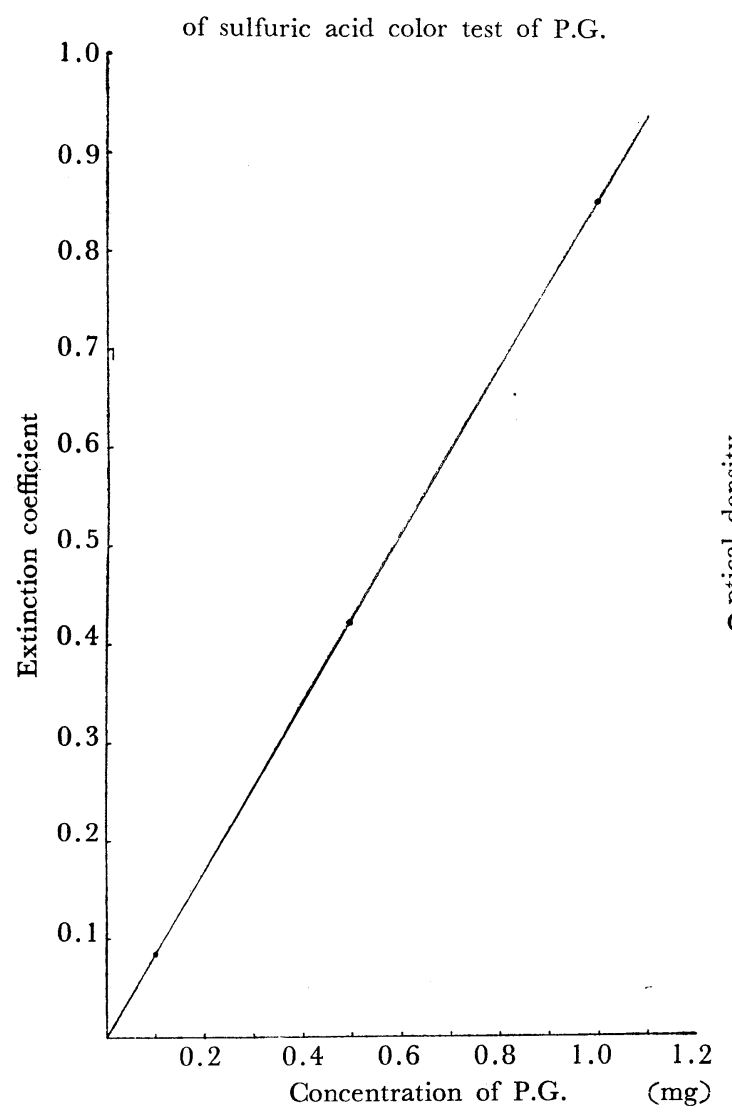

Fig. 10 Spectral absorpsion curve of

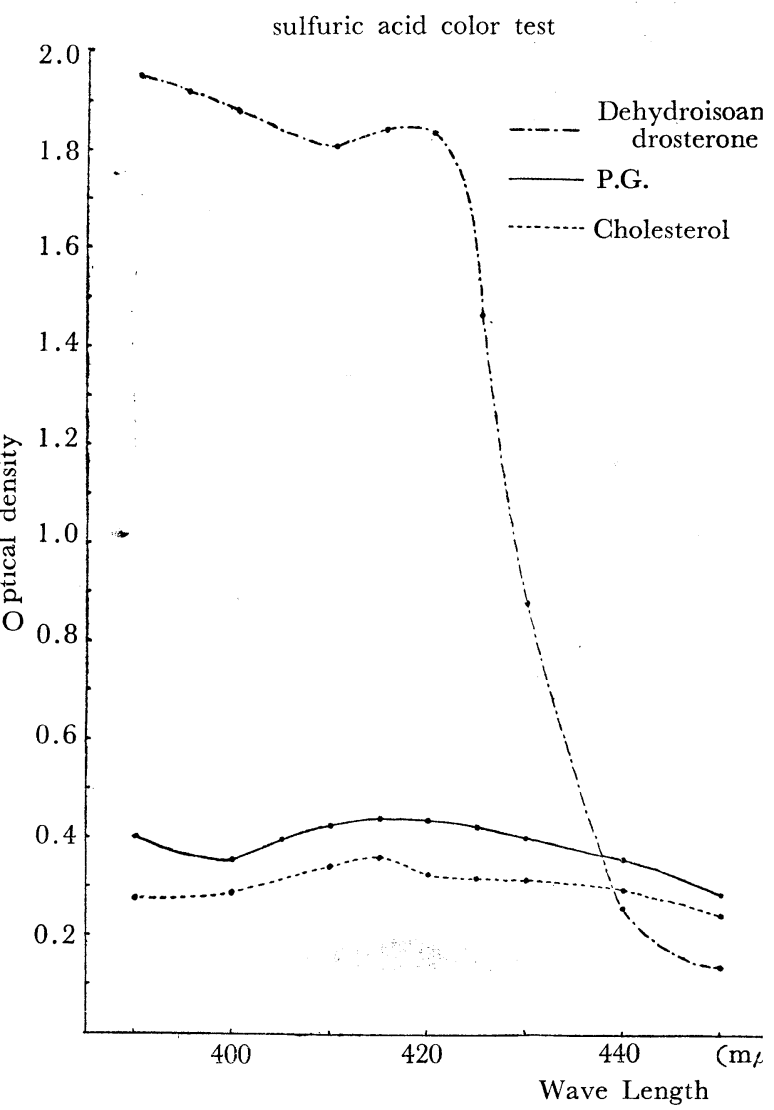

後，各波長についての absorption curve を画くと Fig· 8 に示す如く, $415 \mathrm{~m} \mu$ 波長の最適であることが窥えるが， Beckman 以外の比色計を使用する場合を考虑して，乙れ と大差のない $420 \mathrm{~m} \mu$ 波長を使用するとと〉した。

(c) standard curve 以上の実験より濃硫酸10ccにて 70 分間是色せしめた後， $420 \mathrm{~m} \mu$ 波長を用いた場合の standard curve 在作成すると，Fig. 9 の如く少く共1.1 mg ま では略々 Lambert-Beer の法則に従つた。

Table 3. Recovery test of P.G.

\begin{tabular}{|c|c|c|c|}
\hline 尿 量 & $\stackrel{\text { 添 }}{\text { P. G. 量 }}$ & $\begin{array}{l}\mathrm{P} \cdot \mathrm{G} \\
\text { 回収量 }\end{array}$ & 回収率 \\
\hline $500 \mathrm{cc}$ & $1.0 \mathrm{mg}$ & $0.94 \mathrm{mg}$ & $94.0 \%$ \\
\hline $500 \mathrm{cc}$ & $0.8 \mathrm{mg}$ & $0.77 \mathrm{mg}$ & $96.3 \%$ \\
\hline $200 \mathrm{cc}$ & $1 \cdot 0 \mathrm{mg}$ & $0.95 \mathrm{mg}$ & $95.0 \%$ \\
\hline $200 \mathrm{cc}$ & $0.7 \mathrm{mg}$ & $0.67 \mathrm{mg}$ & $95.7 \%$ \\
\hline $200 \mathrm{cc}$ & $0.5 \mathrm{mg}$ & $0.46 \mathrm{mg}$ & $92.0 \%$ \\
\hline
\end{tabular}

内みに前述の結晶を光学的に検討するために,P.G.に関係ある dehydroisoandrosterone 及び cholesterol について，同样な spectral absorption curve を作成し，P.G.のそれと比較すると Fig. 10 亿示す如く， cholesterol のそれはP.G.のそれに稍々近似するがP.G.の如く，420m $\mu / 410 \mathrm{~m} \mu$ spectral ratio が必ずし も1より大でないととが認められる.

第 5 項 回收試験 男性尿に前記結晶を混入して前述の操作を施行し, 闸収試験を行つた結果，その回収 率は Tab. 3 の如く92.0〜96.3\%の满足ずべき值を得た。

\section{第 4章 結辞}

現在最も正確なP.G. 定量法であり，就中微量定量法としては，確実無比なるものであると皊えられてい 
る硫酸による此色定量法は極めて鋭敏であるが，P.G.のみに特有な反応でないととが明かとならた今日，そ

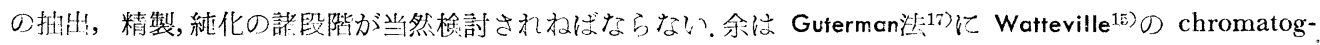
raphy 学採用し，乙れに若干の改良を加えて実駼方法とした。而して比色定量法に於て最急問題となる呈色 物質に一いて，その抽代分離せる結晶が昇華性を有するととを発胃し，純粋に昇華晶出せしめた結鮊像を提

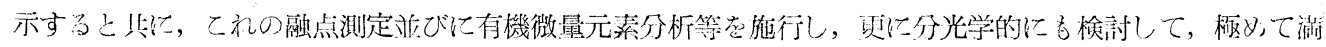

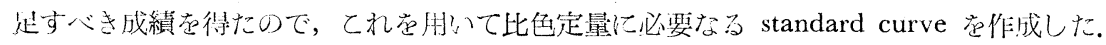

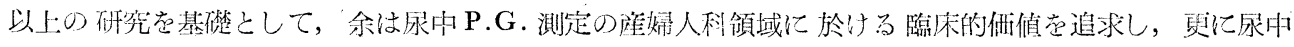
P.G.が prog. の産生並びにその代謝機序及び T.B.H. 等と如何なる関係にあるか等について究明した成紹 宣捘篇に述べる。

$$
\text { 後篇臨, 床実駚 }
$$

\section{第1章 緒言}

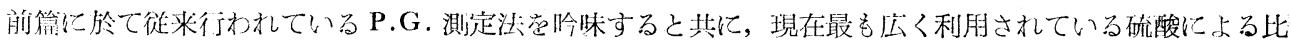

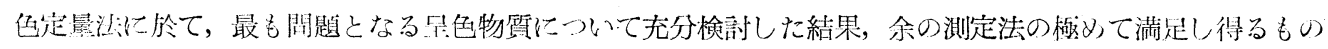

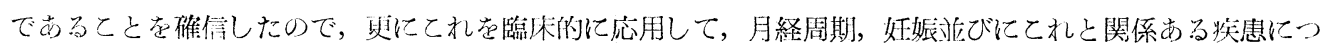
いて，P.G.の尿中排泄量を測定し，更に大々の場合に於ける T.B.H. の影響を追求して，興味ある成績を 得た。尚補充実駼として prog. の他，DOCA，Testosterone，ACTH，等老当投与して尿中P.G.の態度を究

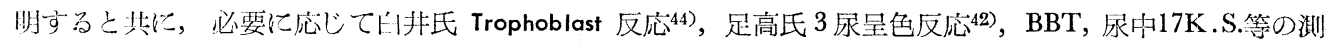
定並びに開腹検查をも施行して成績を检討し，以て体内 prog. の産生並びにその代謝機序に関して種々考 察死試みた。

\section{第 2 章 月経周期と尿中 P.G.排泄量及びこれと T.B.H.との関係}

\section{第 1 節 正常月経周期と尿中P.G.}

第 1 項 実験目的 1924年荻野が排卵は次回月経開始前12１6日の間に行われるとして，従来の伝統的見 解䘮打破したととは，あまりにも有名である. 又 Knaus は prog. が子宮筋の pituitrin 感受性在低下せし めることより，子宮内压の変化苍 kymograph 亿描写して，排卵が月経間期に行われるととを実験的に立証

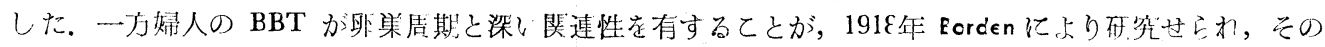
後 Davis ${ }^{24}$ ，Fugo，Tompkins，藤井等に上つて月経周期の後半に於けるBBT の上昇が， prcg. U作肪に上る ことが判圳し，排卵と密接な哭係を有するととが明かとなつたので，位く臨床的に応用されるようになつた。

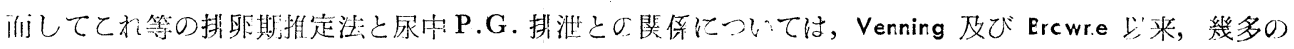

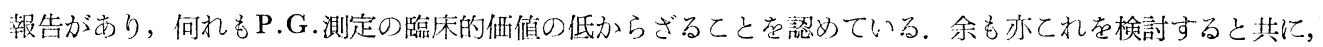
他方 T.B.H. を投与して，月経党人工的に移動せしわた場会の P.G. 量党浿定し，T.B.H.の luteinizing effect 並びに luteotrophic effect 究明せんとして次の如き実験を行つた。

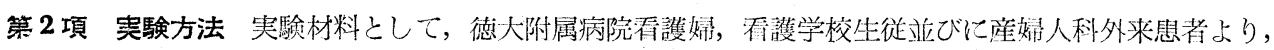

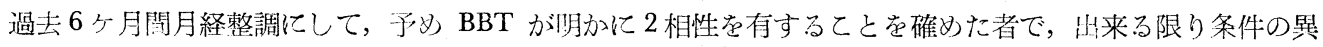

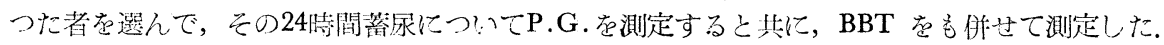

\section{第 3 項 実験或績}

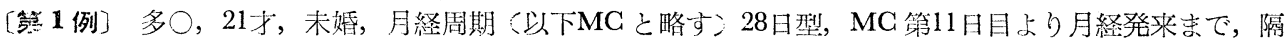
日に尿中P.G.を測定した．Fig. 11〔a)に示す如く，BBTは第14日より高温相に移行し，尿中P.G.は第15 日に至つて始めて認められ，第21日に至つて最高 $4.1 \mathrm{mg}$ 示し，MC.第27日まて持続した。而して第29日に 月経の発来営見た。

[第 2 例〕前記婦人にMG 第22日より，T.B.H. 20F.B.U. 宛連続 3 日間投与した。尿中P.G.はFig.11 (b) 
に示す如く，BBT が高温相に移行した第14日に始めて認められ，T.B.H. 注射終了日のMC 第24日に於て最 高4.6mg苍示し，次回月絿诘 4 日間遅延し，第32日に漸く発来した。

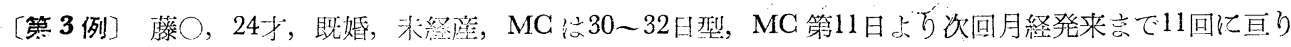
测定した，成績は Fig. 11 (c) の如く，BBT は第16月上り高湿相を示し，P.G. 沈その前月卡認められ， MC第19日に至つて最高 $4.7 \mathrm{mg}$ 党示した。

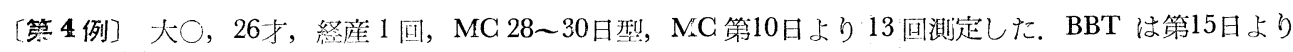

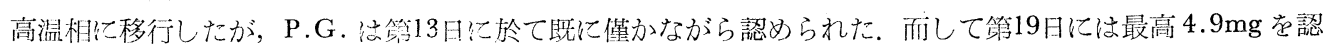

Fig. 11 The amount ofP.G. in urine at the normal periods

[a]

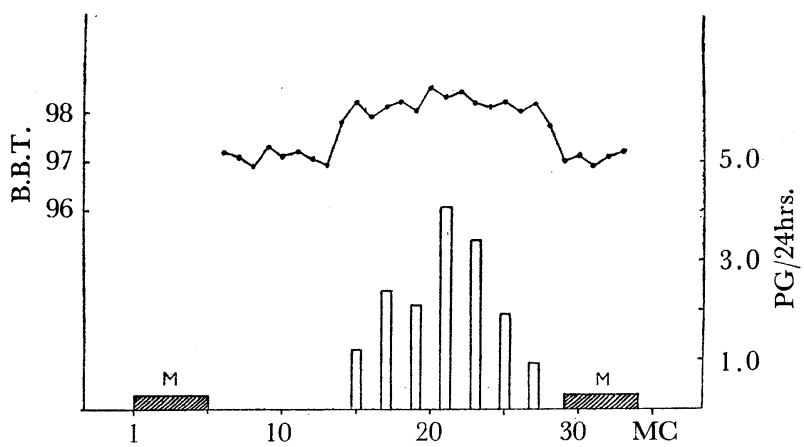

[b]

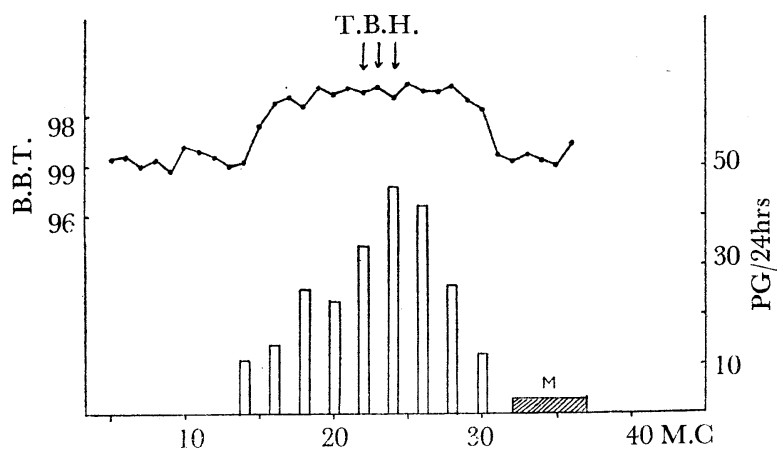

[c]

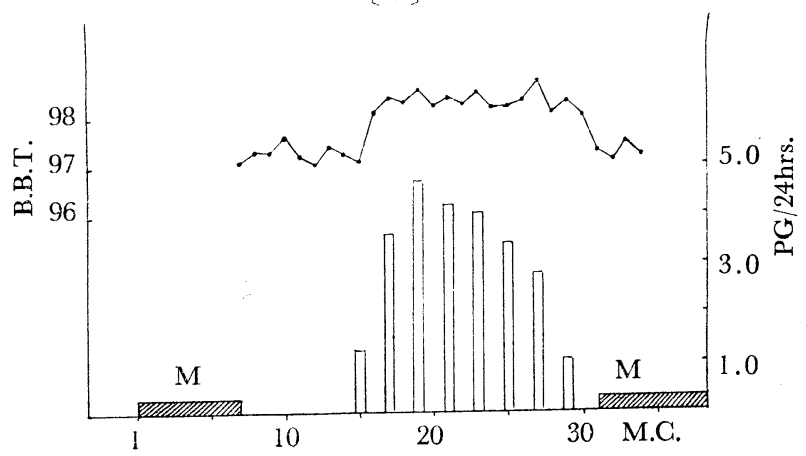

め, 第29日より BBT は下降し始め, その翌日月経が発来したく Fig. 11 (d)).

〔管 5 例] 中。，39f，経産 6 问， MC 30 日型，MC第12日より17问に 亘つてP.G. を測定した. BBT は第 15日上り高温相を示し, 第29日に月 總が発来した，尿中 P.G.は第15日 より第28日まで持続的に排泄せられ， 最低 $0.8 \mathrm{mg}$, 最高 $4.6 \mathrm{mg}$, 総排泄量 $38.5 \mathrm{mg}$ であつた (Fig. 11 (e)).

[笘 6 例] 前記婦人にMG第 6 日 (月経直後) より，T.B.H.20F.B.U. 宛連続的に 3 日間投与した。 Fig. 11 (た)示す如く, BBT は第13日よ

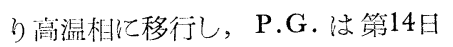
に始めて琵められ，第27日に月経の 発来を見た。 その聞のP.G. 量纪最 低 $1.1 \mathrm{mg}$, 最高 $4.8 \mathrm{mg}$ であつた。

[第7例]江○，24才, 未婚, MG 30日型，MG第12日より P.G. 測定 虚開始した。 BBT は第16日より简 温相に移行したが，P.G.は第18日 に突如 $2.3 \mathrm{mg} の$ 排泄が譛められ，第 26 日には $3.9 \mathrm{mg}$ を示し, その後稍々 下降し始めたので第29日よりT.B.H. 友每日 20F.B.U. 宛 3 回連続投与し た処，P.G.量は再び堌加し，MG第 33 日には最高 $4.1 \mathrm{mg}$ を示し, 月経は 約 1 週間遅惩し，第37日に発来した。

(Fig.11 (g)).

[管 8 例] 野○，37才，経産 3 回， MC 30～32日型，MC 第12日上り测 定老開始した. BBT は第15日より 高温相を示し，P.G.は第16日より 認放らた。 而して MG 符22日より 


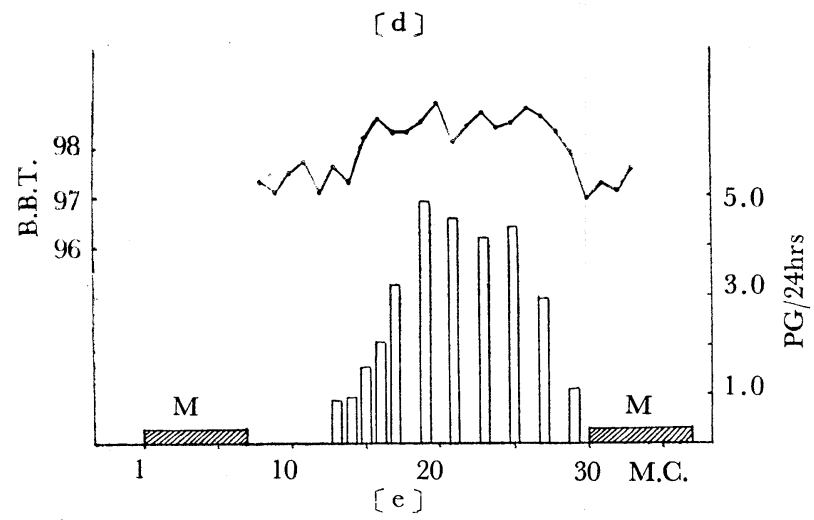

T.B.H. 20F.B.U. 宛 3 日間連続投 与した処, Fig.11 (h) に示す如く, P.G.は稍々增量したが子宮腔部癌 のため，MC第31日(次同月経予定 1) 飞開腹手術范施行した。左側甽 坚に 1 㑉の新鮮黄体が認少られ，子 宮内膜况肥厚し, 組織学的飞腺上皮

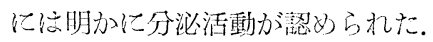

第 4 項 考按 以上の实験上り婦 人性周期於於当尿中P.G. 排浛状 況を矮う時, P.G. 黄体期に於て 排泄せられ，正常周期存有する㷌人

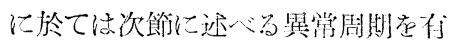

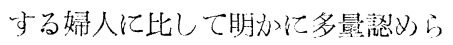

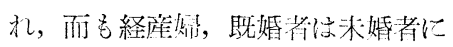
比して幾分堌顽して打り, 尿中P.G. 排泄量は卵紧機能をよく反映する。

又排卵期之 P.G. 排㳻時期との関 係について Venning, Browne ${ }^{2 \overline{)})}$ の他, 最近 Marrian 26) 等结中間痛或は中間 期出血等の如き排卵徽候出現後 24 48特間にしてP.G.の排泄が開始す ると報告している。他方 Rogers， Sturgis ${ }^{27)}$ 等は BBT とP.G.と尼同時 飞測定して，9例中 4 例は BBT 上 昇前に，3 例は上昇日に, 残りの 2 例が上㫧後に P.G.の排泄を俧めた と述へている.本実験に於ても第 3 , 4 例に於て BBT 上昇前に P.G.の 排泄が誻められた。抑々排卵期推定 法としての P.G. 測定の価值を検討 するならば，次の事柄存過すると とは出来ないであ万う。即ち Hoffmann ${ }^{28)}$ 等力゙成熟卵胞或は破綻甽胞 中に睡に prog. の存在苨認好, 又 Buxton，Engle ${ }^{29)}$ 等は体温変動期飞行 つた開腹手術時の統計的観察より, BBT の䇾動期は単に排卵期が近い とと党示すにすざないと結論して打 り, Plotz, Darup 5) 等も同じ㭙期々於 ける開腹手術の卵巣所見が等に末期 の成熟卵胞のみで, 黄体は何等棌め られないに拘らづ゙，術前 24 時間に於 
[h]

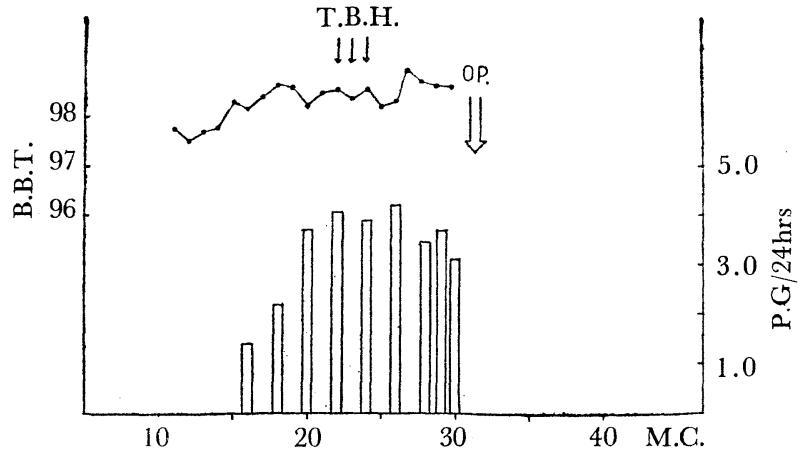

て既に P.G. 老証明し得たといつて いる. 乙れ等の事䒠は当然排卵前に 姐に尿中 P.G. 排沮の開始, 或は BBT 高温相の発現を暗示し, 延い ては排卵に対する prog.の必要性さ 省考される. 又 BBT 注全月経周 期中の測定によつて，始猅卵期 の推定が行われるが，乙の点排卵之 密接な関係のあるる尿中 P.G.の出現 時期堂迫求するととによつて充分補 強され，益々その真価を発掩するも

のと思考される.

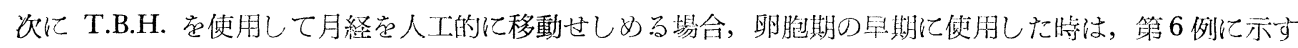
如く幾分早期に P.G. の排泄が認められるにすぎなかつた。然るに黄体期に投与した場合は第 2, 7,8 例に 示す如く, 黄体期の延長之共に P.G. 增量し, 殊飞黄体期の後半に於て投与した時は, その增量は比較的 著しく，T.B.H. による黄体活動の刺㦸乃至賦活作朋が䂓える。因みに補充実験の項に於て述べる如く，去 勢婦人に T.B.H. 在投与しても尿中P.G.には影響が喼められない.

以上正常月経周期に於ける応用として，尿中P.G.の測定は排卵期の推定及び黄体機能を筧知する上に， 重要な役制を演ずるものと思考される.

\section{第 2 節 異常月経周期と尿中P.G.}

第 1 項 実験目的 初潮期, 開経期に於ける月経は，無排卵性であるととが多いと喧伝されているが，成 熟婦人に於ても特に不妅つ婦人には，乙の無排卵性周期を示すものが相当あるてとが知られた。 即ち Novak は48\%，Griffith は38\%，Siegler は29\%と報告しているが，何れも子宮内膜検查法によつたものである。然

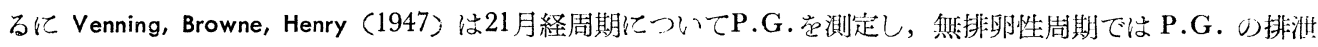
を認为ずと報り゙，又 Mack 等30)（1949）は更に BBT をも測定して，2 相性を示さずP.G.も認められない 例を無排卵性周期であると推定している．余も亦てれを検討すると共に，排卵障碍に基くと考えられる機能 性出血に T.B.H. の上く奏効する事実及び T.B.H. の初期乃至極期反応として, 弤等率の增加する事実上り,

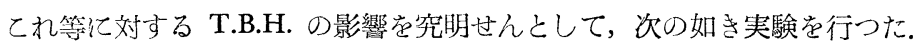

第 2 項 実験方法 実験材料汇は徳大産婦人科入院並びに外来患者及び看護婦の中ょり, 月経不順, 不弤 症, 授乳期, 更年期等の無排卵性周期の可能性ありと考元られる者を選んで, その24時間㢣尿についてP.G. の測定を行うと同時にBBT をも測定した。

\section{第 3 項 実験成綪}

〔第 1 例〕木○，22才，未婚，MGは不整にして大約 50 ６0日，月経困難症を伴う。MG第 8 日より次回 月経発来の第57日京で，BBT の測定を行つたが第39日以後，僅が上昇せるのみで，明かな 2 相吽は認妇

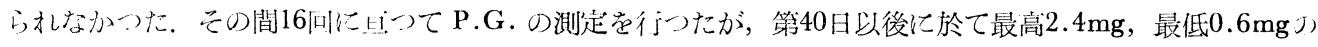
低值を示した。而して同婦人に次回MG 第 7 日より埛日に T.B.H. 离 20F.B.U. 宛 3 回投与した処，第22日 より0.4mgのP.G.排㴹が認められ，BBT は第20日より幾分上昇すると共に，P.G.量各漸次增加して最高 $2.9 \mathrm{mg}$ 空示し, 籍 36 日亿月経が発来した。

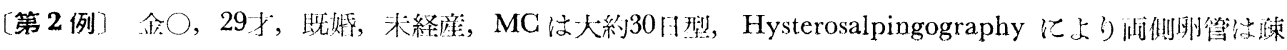
通性であることが訫められ，MG第5日より BBT 及びP.G.の測定を行つた．BBT は単相性にして，一定 の規律は認められず，P.G.は11回に亘り測定したが，第15日に漸く $0.8 \mathrm{mg}$ つ排泄が認められ，第31日に月

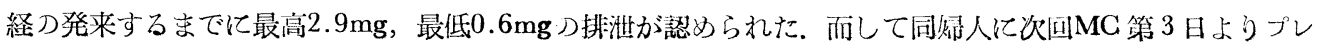


ホルモン 500 単位宛隔日に 5 回, 次でオバホルモン 1000 単位宛隔日に 5 回, 更に 3 日毎にオ、ホルミンルテ ウム $5 \mathrm{mg}$ 宛 2 回投与して，第32日に月経の発来をみた。 BBT は prog. 投与瑟日より僅かに上抟したが， P.G.は乙れより先，第19日より0.4mgの排泄が認められ，最高 $3.2 \mathrm{mg}$ ，最低 $0.4 \mathrm{mg}$ の排泄量を示した。

[第3 例〕山O，44才，経産 4 回，MG は従来整調であつたが，約 2 年前より漸次不順となり，現在約 40 ～50日型となつている．MC第7 日より次回月経発来の第46日まで，BBT 及びP.G.の測定を行つた．BBT

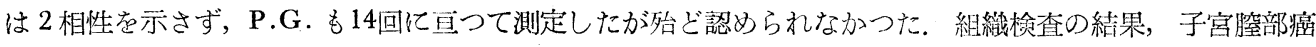
と診断され，MC笏14日に開腹手術を施行したが，卵巣:は両側共菱縮し，黄体は勿諭，卵胞つ発育も認めら れなかつた。

〔第 4 例〕松○，26才，経産 2 回，MG は28日型，現在授乳中にして，分婏检 106 日目に始妙て月経方溌 来し，続いて141日目より再度月経が 5 日間あつた。分婏後147日目よりBBT 及びP.G.の測定壳行つたが，

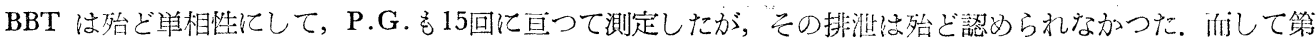
174 日即ちMC第 6 日より T.B.H. 存隔日に 20F.B.U. 宛 5 回投与した迈，BBT はMC第14日より上昇し,

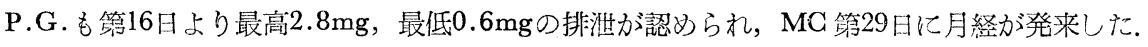

䇫4 熕 考按 以上の成續より考按するに，定型的 BBT 示きず，筫常月経周期を有する婦人に於ては 正常周期を有する婦人に比して，尿中 P.G.の排泄は著明でなく，その排泄量は卵栄機能殊飞黄体活動をよ く反映すると思われる．又無排卵性周期の決定に関して，Novak は子宮内膜检査法が最も優秀であるとい つているが Hamblen ${ }^{31)}$ は子宮内膜検查の結果と尿中 P.G. の測定成續と一致しない場合が少くないといつて 扔り，又排卵及び黄体の形成が行われても，子宮内膜が分泌期を星さないととが少くないといわれている. 從つて無排卵性周期の決定には，単に子宮内膜検查法乃至 BBT の測定のみでは不充分で，P.G. 測定の必

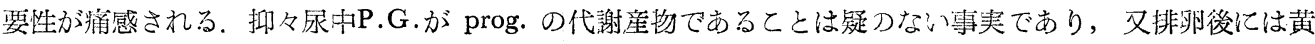

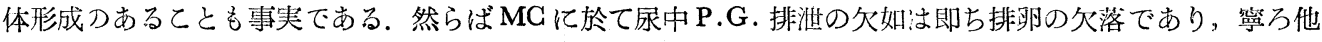
の如何なる検查法沉も勝つて無非卯性周期つ確実な指標となり得ると恩考される.

尚異常月経周期乃至機能的不妊正に於て，T.B.H. は卵巣機能を高㚈，上く奏勃するととは臨床的に 認め られているが，か〉る場合，第 2 例刀如く從来つホルモンを順次補足投与する方法よりも，T.B.H. 投与の 方がよくP.G.の排泄を促した。

\section{第了章＼cjkstart妊娠及びこれに関係ある疾患と尿水 P.G. 排泄量}

Fig. 12 The amount of P.G. in urine at the normal conception

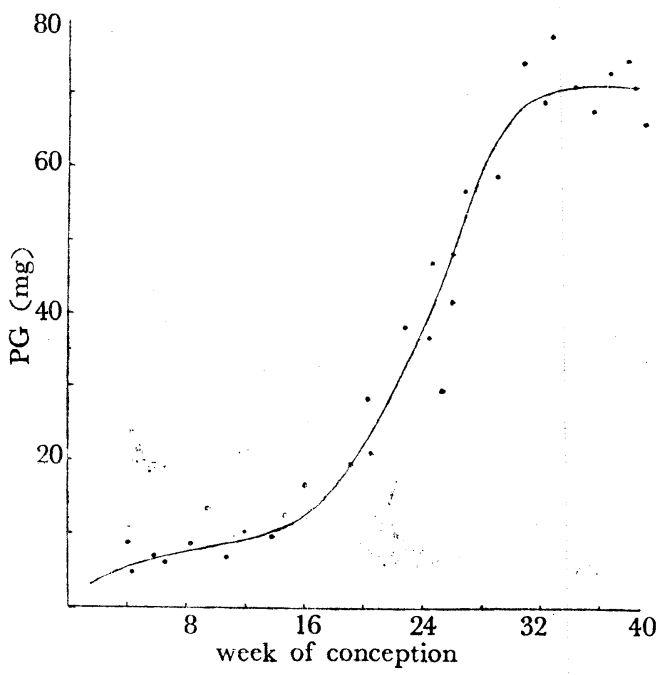

第 1 節 正常妊娠，分婏，産裖時の尿中 P.G. 第 1 項 実験及びその成経 実験材料には德大 産婦人科入院患者立びに特にての実験に協力して くれた外来患者の24時間蓄尿を使用した，正常姄: 娠時に於ける娃娠各週のP.G. 量は大約 Fig. 12 亿 示す如き curve 它画く. 即ち第16週以後, 急速に 上昇を示し, 第32週前後で最高に達する. 而して

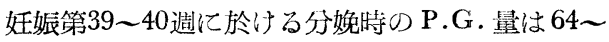
$76 \mathrm{mg}$ で，産褿時に於ては急速汇減少し，分婏後 100時間以内にP.G.は認められなくなつた。㕛特 亿初産婦 2 名について，第 8 週上り 4 週每に24時

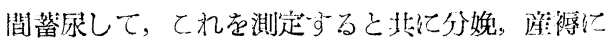
至るまで，逐次その変化を観祭した成績は Tab.4 に示す如くである.

第 2 項 考揬 一般に妊娠初期13亿於汁るP.G. 1 日の排浛量法測定者により差があり，大約 3 
Table 4. The amount of P.G. in urine at the normal pregnancy, parturition and delivery

\begin{tabular}{|c|c|c|c|c|c|c|c|c|c|c|c|c|c|c|c|c|}
\hline \multirow{2}{*}{$\begin{array}{l}\text { 症 } \\
\text { 例 }\end{array}$} & \multirow{2}{*}{$\begin{array}{l}\text { 年 } \\
\text { 令 }\end{array}$} & \multicolumn{9}{|c|}{ 娃娠 週 の P. G. 量 (mg) } & \multicolumn{2}{|c|}{ 分 婏 時 } & \multicolumn{2}{|c|}{ 产 } & \multicolumn{2}{|l|}{ 裖 } \\
\hline & & 8 & 12 & 16 & 20 & 24 & 28 & 32 & 36 & 40 & P.G. & . $\left|\begin{array}{l}\text { 厡量 } \\
(\mathrm{cc})\end{array}\right|$ 時間 & $\left|\begin{array}{c}24 \\
\text { (時間) }\end{array}\right|$ & 48 & 72 & 98 \\
\hline 大 0 & 22 & 8.2 & 11.3 & 19.8 & 27.6 & 39.1 & 47.4 & 64.4 & 65.1 & 62.7 & 36.1 & 94018 & 18.2 & 9.3 & 3.1 & 0 \\
\hline ○ & 24 & 8.9 & 10.1 & 18.2 & 24.8 & 36.0 & 45.1 & 62.8 & 62.2 & 64.1 & 24.2 & 76014.5 & 13.1 & 6.8 & 0 & 0 \\
\hline
\end{tabular}

$40 \mathrm{mg}$ 芆報告し，意見も暴つているが，本実験に於ては10 $\mathrm{mg}$ 内外を示し，黄体期のそれと左程著明な差異を

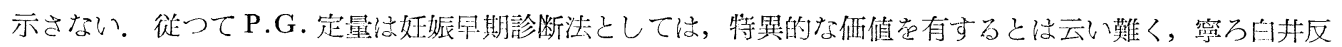
応或は足唯反応在施行する方が賢明で节る。

又姃娠第16週以後に於て，P.G. 排淮の急に增量するてとは異論のない処であるが，妊娠末期 73 に於ては

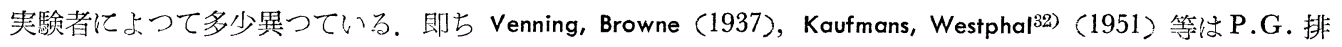
洲曲線は略々同じ傾问を辿つて 分婏に至るとい〉, Portes ${ }^{33)}(1941)$, Jones, Delf 及び Straw ${ }^{34)}$ (1944),

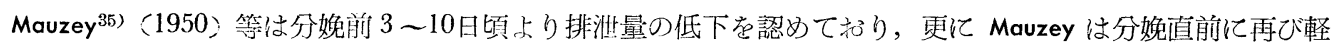
い上昇をみている，本実験に於ては姃娠各週に於ける個々の成續の他，同一弤婦について連続的に測定した 結果，第32週前後に於て最高に達したP.G.は，以後同様な排泄量を示しつ〉分婏まで持続し，分婏に至り て減少し，胎盤の娩出と共に急速に下降するととを認めた。 ての矛は明加に胎盤の prog. 産生分泌を裏付け るものであり，而も姃娠の比洨的早期に於てさえ，妊娠黄体を剔除してもP.G.排澌に著変なく，妊娠も継続 するという Llusia ${ }^{26)}$, Venning ${ }^{37)}$ ，Davis ${ }^{24)}$ ，前山 ${ }^{38)}$ 等の報告より考按しても，弤娠初期に於て既に妊娠の維持， 継続に対して黄体及び胎盤の雨者が内分泌的て相互協調的役割を演ずることは甚だ興味深きととであり，後 述の T.B.H. の切迫流早産に詨す万效果にも一示唆老与えるであ万う.

\section{第 2 節 妊娠中毒症時の尿中P.G.}

弤娠中毒症の本態に関与る硎究は，枚挙に遑のない程であるが，てれを妊娠中のホルモン代謝異常に求め

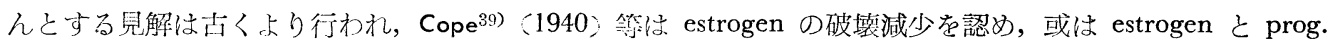
の量的不均衡によるともいわれている. 余も亦晚期妪娠中毒症に於て P.G. 排泄状沇考検討し，乙れと臨床 症状並びに治療的效果との關係をる追求してみた。

第 1 項 実験及びその成績 実験材料としては徳大産婦人科入院患者の篦尿を使用した.

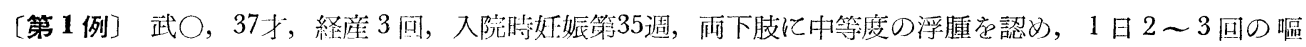

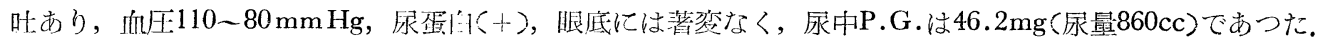
入院第 8 日にはメチオニン投与等の加療により嘔吐は止み, 浮腫も尿蛋白も殆ど消失した. 而して P.G.は $54.7 \mathrm{mg}$ (㽷量 $1250 \mathrm{cc}$ )と增量し，10日にして退院した。

[第 2 例]山○，34才，経産 1 回，入院時第29週，兩下肢に中等度の浮腫があり，血圧は166〜 $110 \mathrm{~mm} \mathrm{Hg}$, 㽷蛋门(H)，眼底には血管の笛純な硬化を示す他，浮腫等は認められない，而して氺中P.G. 量は $39.8 \mathrm{mg}$

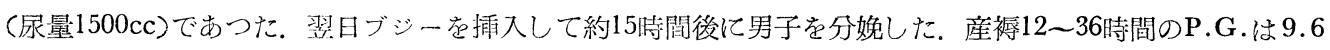
$\mathrm{mg}$ (尿量 $1250 \mathrm{cc}$ )であつた.

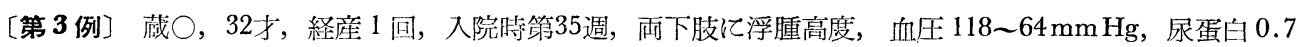
$\%$, 眼底には浮腫著明にして，尿中P.G.は48.2mg(尿量1450cc)であつた。而してメチオニン $500 \mathrm{mg}$ 宛 4 時 間每に 5 回投与後 24 時間のP.G.50.3mg(尿量 $1270 \mathrm{cc}$ )で，更に 3 日後グロンサン $200 \mathrm{mg}$ 宛 4 時間毎に 5 回投 与後のそれは $54.1 \mathrm{mg}$ (永量 $1400 \mathrm{cc}$ )で尿歪北は0.3\%であつた.

〔第 4 例〕前記婦人が第 38 週に一時退院して符 40 週に再び入院した。浮腫益々高度，血圧 $130 \sim 86 \mathrm{~mm} \mathrm{Hg}$, 尿蛋尚 $6.3 \%$ にして眼㼟所兒も悪化し，人ハトサルファレイン試験 $15 \%$, 血清高田反応(一), フェノールズ ルフォフタレイン排泄試験 $25 \%(2$ 時間)であつた. 而して尿中P.G.は $47.3 \mathrm{mg}$ (尿量 $960 \mathrm{cc})$ で，その後 4 回 
に亘る測定值は治療と共に渐次増量し，分娩前 3 日に於けるP.G.量は $52.7 \mathrm{mg}$ であつた。

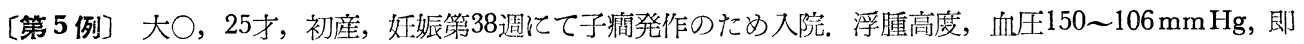
日腹式帝王切開術を施行した 術前 4 洔間尿のP.G.量は $6.4 \mathrm{mg}$ (尿量 $230 \mathrm{cc}$ )で尿蛋|゙は $8 \%$ \%あつた。而し

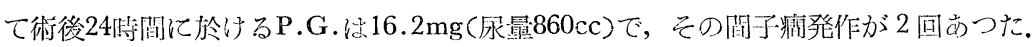

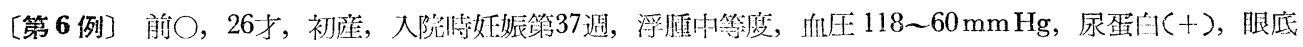

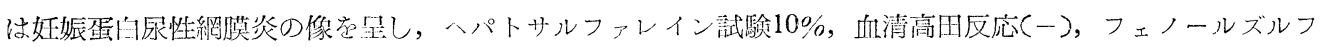

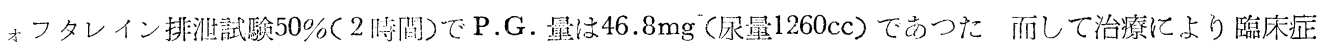

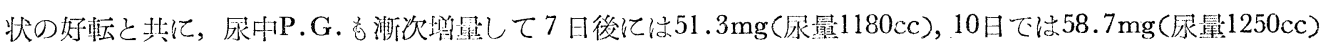
であった。

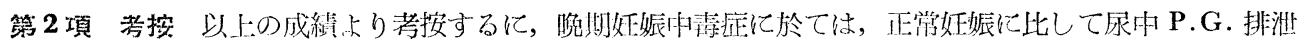

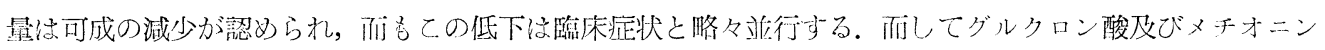

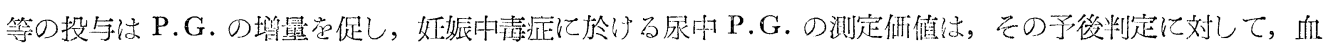
中沃度酸値や残余空素等に匹敵するものと思考される。

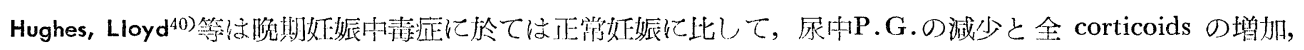

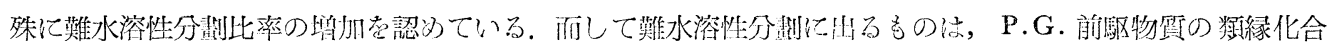

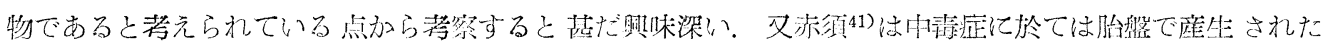

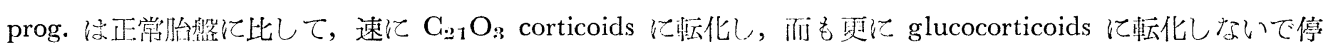
止するるのであるといつている.

抑々prog. の体内代謝は他の $\mathrm{C}_{21}$ steroids と同様に終末 pregnane 誘導体に邀元されるが，そのA環に

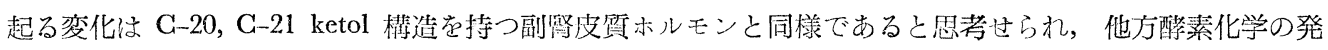

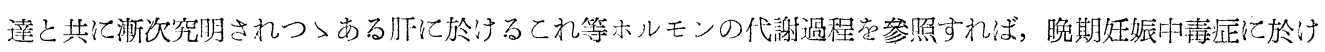
るホルモン代謝異常る推察される。然しながらか上うな尿中P.G.排泄量の減少には, 胎艋代於ける prog.の

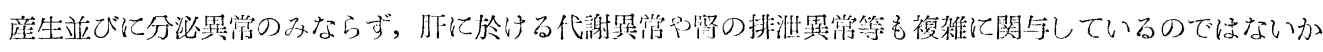
と推量される。

第 3 節 流早麾時の尿中 P.G.

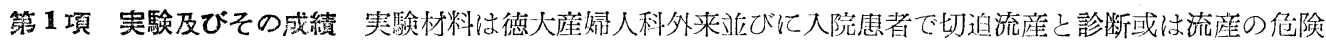
ありと推定された 4 例について，T.B.H. 或は prog. 在投与して策位尿量中のP.G. 学測定すると共に，足高

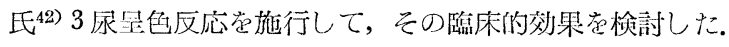

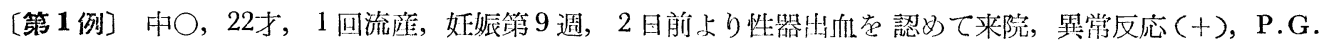
$0.67 \mathrm{mg}$ (尿量200cc中)，T.B.H. 20F.B.U. 宛 3 日间進続投与した外，3 日目に完全止血した。時にP.G.1.52 $\mathrm{mg}(200 \mathrm{cc}$ 中)にして買常反応( -$)$, その後娃娠は継続した。

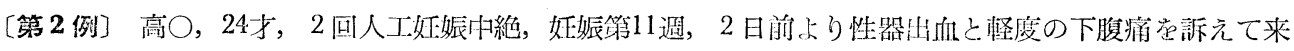
院. 子宮外口開大也ず，買常反応(H), P.G.1.02 mg(200cc中), T.B.H. 20F.B.U.宛 3 日間連続投与して, 3 日目に止血した。第 2 日目に於けるP.G.は $1.27 \mathrm{mg}(200 \mathrm{cc}$ 中), 第 3 日に於ては異常反応( - ), P.G. 2.40 $\mathrm{mg}(200 \mathrm{cc}$ 中)で以後姄娠隹順調に経過した。

〔第 3 例 藤 $\bigcirc, 21$ 才, 未経産, 姃娠第21週, 転倒して 1 日前上り下腹部不快感と少量の性器出血を訴えて 来院. 異常反応 $( \pm)$ ，トリプトファン反応( + ), ヒスヂチン反応(H), P.G. $2.86 \mathrm{mg}(200 \mathrm{cc}$ 中)で同様にして T.B.H. 3 回連続投与した。出血は 2 日目に止つたが，第 3 日目に於けるP.G.は $3.28 \mathrm{mg}$ ( $200 \mathrm{cc}$ 中)，第 4 日 目では $3.67 \mathrm{mg}(200 \mathrm{cc}$ 中)で, 关の後来院しなかつた。

〔第 4 例〕下○，26才，2回経産，妊娠第17週，急性虫兆炎のため開腹手術を施行した。術前P.G.は3.41 $\mathrm{mg}$ (200cc中) で術後18時间目に採取せる尿中P.G.は $2.91 \mathrm{mg}$ (200cc中)であつた．以後流産防止の目的で prog. を毎日 $5 \mathrm{mg}$ 宛投与したが，術後 3 日目の随時尿 $200 \mathrm{cc}$ 中P.G.は $3.67 \mathrm{mg}$, 第 5 日日では $3.70 \mathrm{mg}$ で流 産の㠛候なく順調に経過した。 
第 2 項 考按 Guterman 43 ) (1949; 《切迫流産335例の中，191例は尿中P.G.が正常值を示し，その中 $82 \%$ が弤娠定継続し，又141例绀正常より低值を示り，その中97\%が流産したと報告している. 本実験位切迫流産

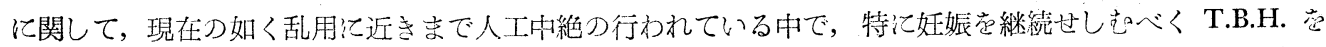
投与した 4 例について行つたもので，従来すべての測定者は24㬨間尿支使用しているが，余法切迫流産に於

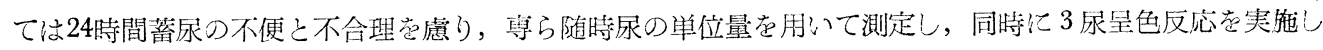

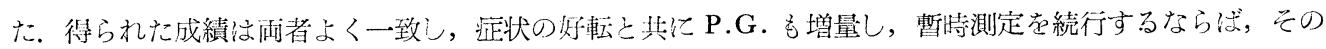
予後判定並びに T.B.H. の効果判定に充分役让つととを認めた。

第 4 節 子宮外妊娠並びに死胎待の尿中 P.G.

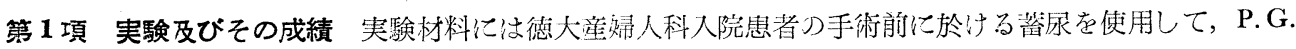

Table 5. The amount of P.G. in urine at the ectopic pregnancy and a dead foetus

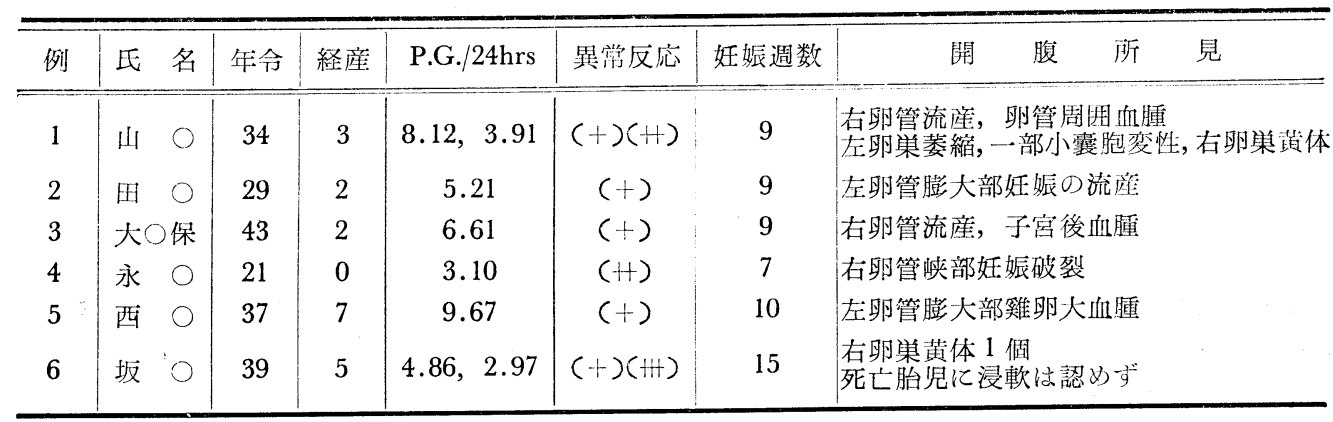

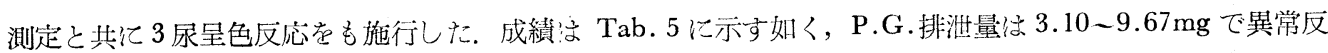

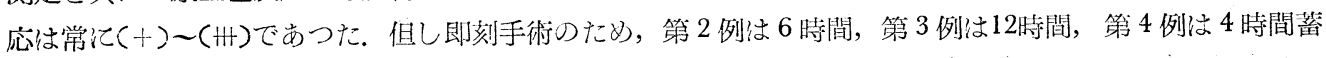

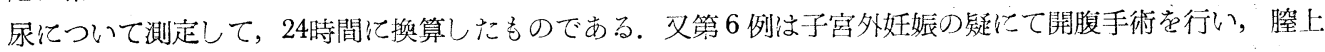
部切断術を施行して死胎( 4 ケ月)であつた例で岕る.

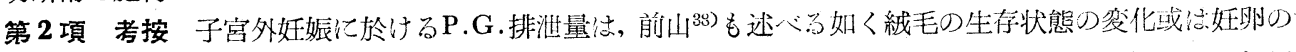

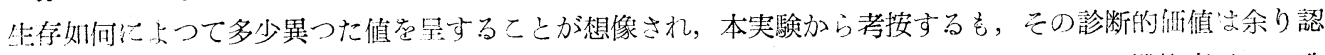

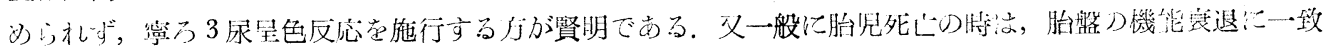
してP.G.量も減少することが推測されるが，第6 例に於ててれを確㢹し得た。

第 5 節 胞状鬼胎並びに䋐毛上皮腫生の尿中 P.G.

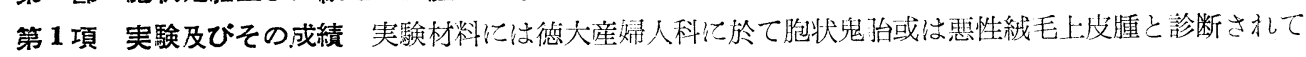

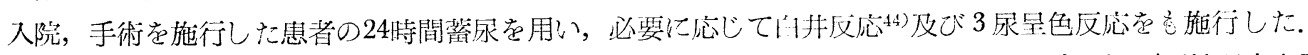

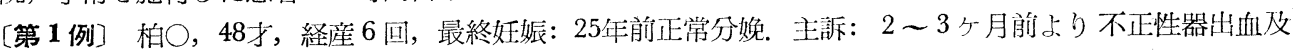

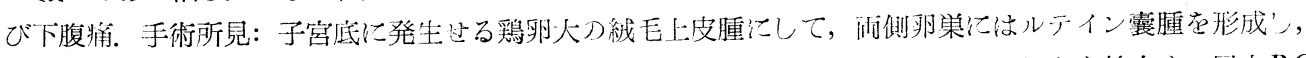

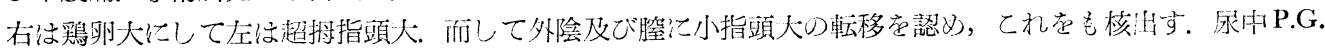

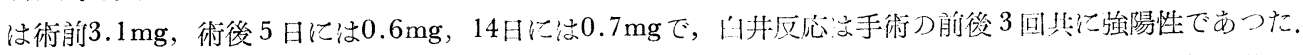

[第 2 例 猪 $\bigcirc ， 40$ 才，経崖10回．最終分娩：約 1 ケ月前妊娠第 11 週で胞状鬼胎搔爬．主訴：搔爬後 15 日

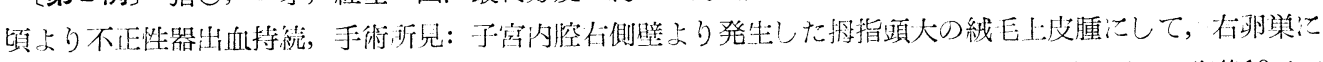

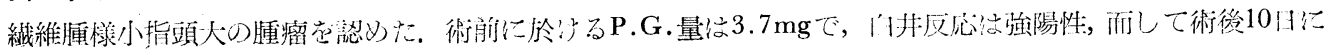

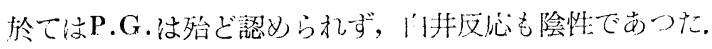

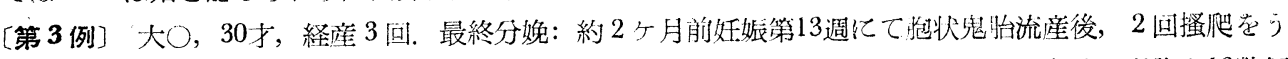

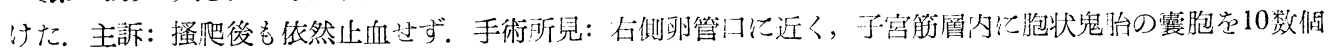

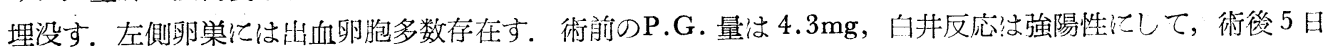
目のP.G.は0.3mgで，第14日に於てはその排沺は認好ら礼ず，白井反応る陰性であつた。 
[第 4 例] 井○，35才，経産 3 回．最終分婏：約10个月前妊娠第11週にて不全流産後，1回搔爬を与く. 主訴：約 3 ケ月前上り不正性器!血持続. 手術所見: 于宮腔内に於て低部及び前壁より発生せる約小先頭大

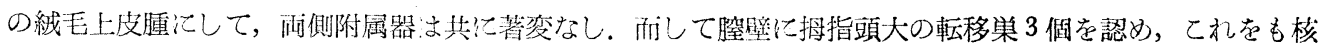

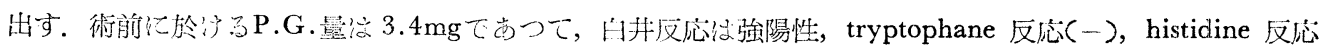

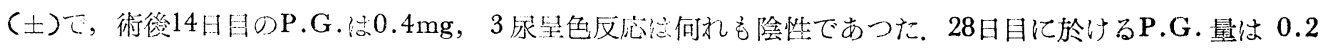

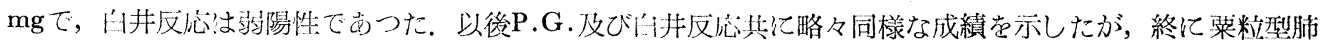
転移疮起して，術後45日目に死亡した。

[第 5 例] $1110 ， 48$ 才，経産 2 回，最終分婏：約 4 年前骨盤位てて生少分娩. 主訴：約 20 日前より不正性

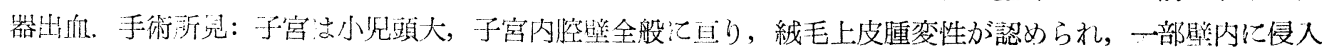

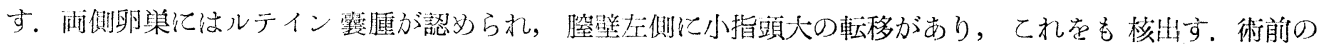

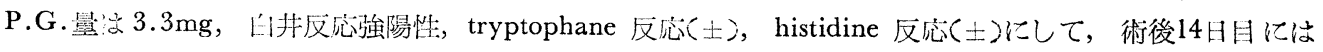
P.G.排泄は諗》られず，白井反灾も㓌性であつた。

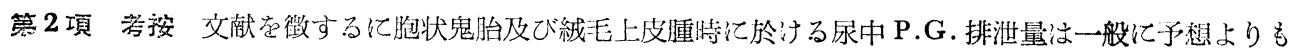
低值であるてとが報告されている。.Thibault de Beauregardは胞状鬼胎後続発せる䋐毛上皮腫に於ては，尿 中P.G.量は chorionic gonadotropin 量て比例すると云い，又 Pigeaurd及び Burthiault45)(1952)は24例の 胞状鬼胎並びそこれに続発した䋐毛上皮腫 3 例てつ、てP.G.を測定して, 流産前に於てはP.G.測定の診断 的価值は低，が，流産後尚高值且つ持続的なP.G.の排泄は絾毛上皮腫の発生を暗示すると云い，而してそ の量は chorionic activity よりも寧万卵巣機能に関係すると述へている。

本丰験に於ては，あまり症例て惠京れず，殊に流産前つ胞状鬼胎については央験し得なふつたが，この後 に発生した絨毛上皮腫に於て，生井反心が陽性てして，P.G．の認められない例には遭遇しなかつた。抑々

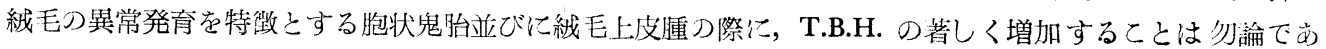
るが，第 4 章に於て述心゙る如く，去等婦人に T.B.H. 学投字してもP.G. 排泄には何等影響が認められず， 又既述せる如く妊脄早期て於てはP.G.排泄量さ黄体期刀とれと著明な差異を示さず，T.B.H. 分泌の減的す

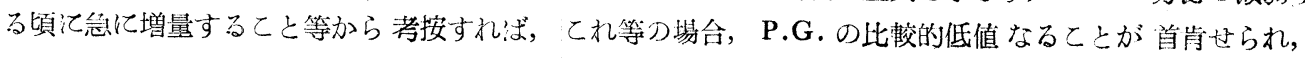

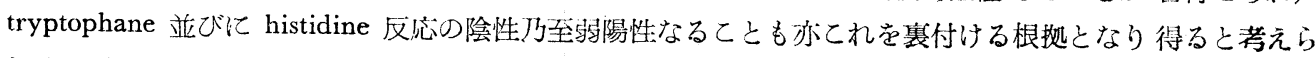

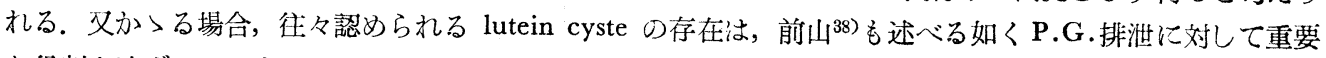
な役割を演ずるとは考え難く，又病柴の大小や転移の有無との間にも比例した関係は認められなかつた。

\section{第 4 章 補 充 実 験}

\section{第 1 節 実験目的}

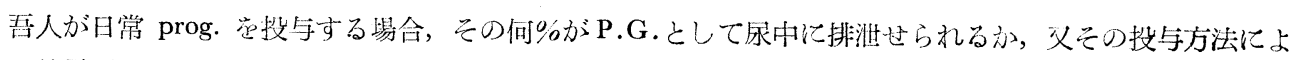

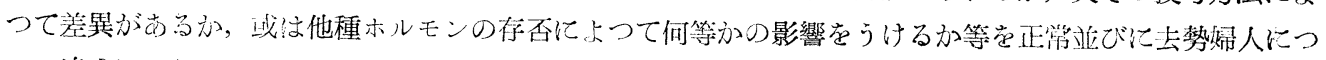

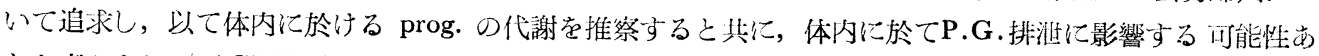
りと考えられる ACTH, Corticoid, Androgen, T.B.H. 等につれて検討せんとして, 次の如き史験学行つた。

\section{第 2 節 実験及びその成績}

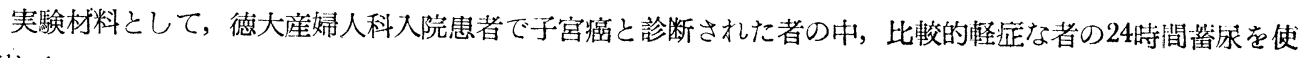
用した。

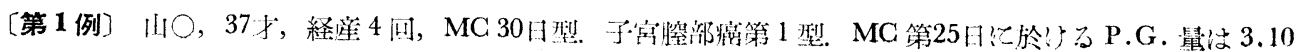

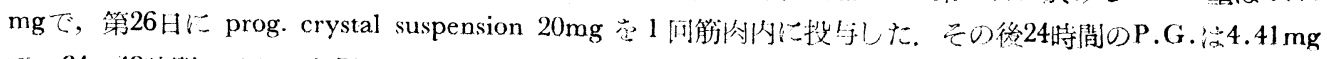

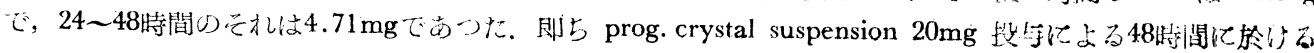

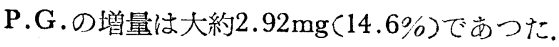

〔第2 例]前記婦人の手術後第31日目に尿中P.G.の存在しないととを確むて，その斐日同様の prog. 20 $\mathrm{mg}$ を投与した処，その後 24 時間に於けるP.G.排泄量は $0.46 \mathrm{mg} ， 24 〜 48$ 時間では $0.92 \mathrm{mg}$ で合計 $1.38 \mathrm{mg}$ 


\section{(6.9\%)であつた.}

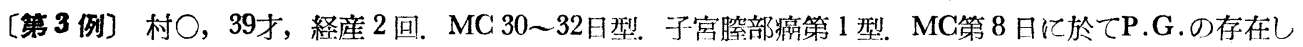

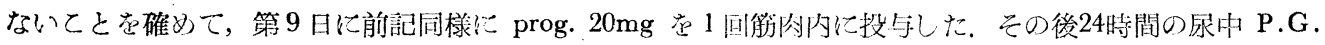
は0.59mg, 24〜 48時間では0.64mgで合計 $1.23 \mathrm{mg}(6.2 \%$ のであつた。

〔第 4 例〕前記婦人の術後第 29 日に proluton intravenous (containing $20 \mathrm{mg}$ prog.) 者 1 回静脈内に投

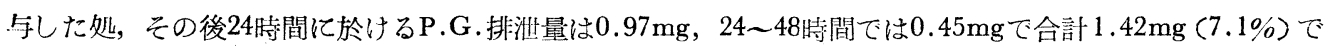
あった．次に術後40日に prog. in oil $20 \mathrm{mg}$ を 1 回筋肉内に投与した. 24 時間後のP.G.量は0.47mg, 24 48佶間では0.69mg，48〜2時間では0.19mgであつた。更に術後第61日に Proluton C (cont. 20mg pregneninolone) 党 1 回経口投与した。关の後 24 㭙間のP.G.量は $0.21 \mathrm{mg}, 24$ 48時間では $0.41 \mathrm{mg}, 48$ 72時間 では0.43mgであつて，72９6㭙間のそれは0.13mgであつた。

〔第 5 例〕 大○，28才，未経産，子宮堔部癌第 1 型。術後第37日より T.B.H. 1 日 1 回|20F.B.U. 宛隔日に 3 昍投与し，2 日後 oestradiol benzoate in oil t 1 日 1 回 $5 \mathrm{mg}$ 宛隔日に 5 回投与した. 更に 2 日後 prog. crystal suspension20mg宛 3 日間連統投与して, BBT, 血中好酸球数, 尿中17 k.s. と共にP.G.の測定老行

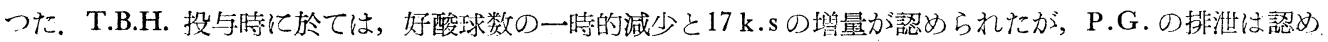

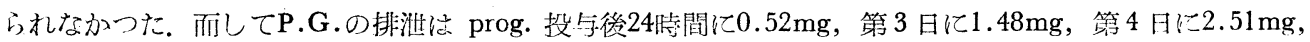
第 5 日に2.23mgで第 6 日には殆ど消失した。 又 BBT には明かな上昇は認められなかつた。

〔第 6 例〕二O，51才，経産 4 回，子宮胠部癌第II型. 術後第61日上勺第 5 例と同㥞にして T.B.H. 及び

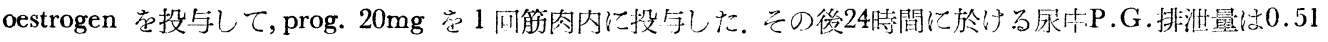

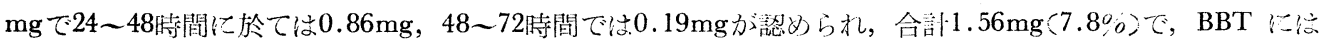
明汃な上舁は笖められなかつた。

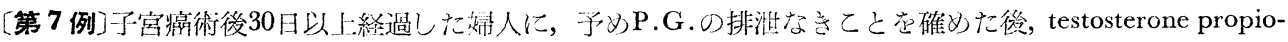

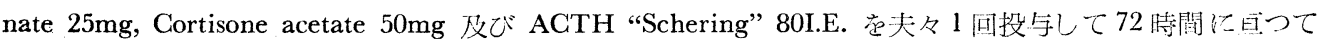
永け17k.s.と共にP.G.を追求したが，17k.s.の変化のふでP.G.の排泄は佲ど䚺められなかつた。

\section{第 3 箅 考 按}

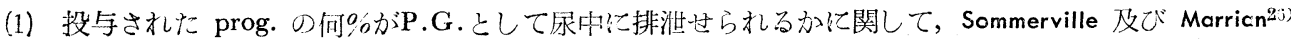

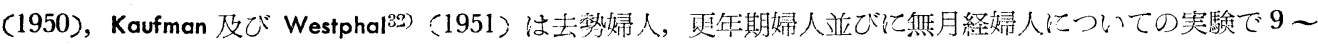

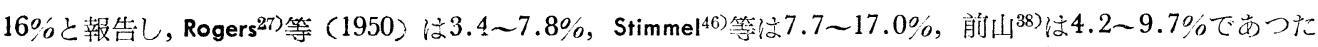
といつている. 本夷験では第 $1,2,3$ 例に於ける如く，投与後48時間に於ける P.G. 排㴖量は，黄体期に於 ては $14.6 \%$ ，卵胞期では $6.2 \% ，$ 去勢時に於ては6.9\%であつた。即ち生体が prog. 作用の影響下にある場合 は，体外加の prog.の還元代謝寻增加するものと思考され，生体に於ける内分泌腺機能の状態によつて差 異のあることが窅われる。

(2) Buxton ${ }^{47)}$, Hamblen ${ }^{48)}$, Darfman ${ }^{49}$ ) 等は健康男子に prog. 在投与した場合, 筋肉内投与よりも経口的投 与の場合が，尿中P.G.の排泄は幾分高度であると報告し，他方 Fisher ${ }^{50)}$ (1953) は男子，去勢婦人及び成熟 䜌人に prog. 筋肉内，経口的，バッカルの 3 方法で投与したが，P.G.量には差異のなかつたことを珰奷＼cjkend， 更に prog. の肺内代謝に関しても音及している. 本実験も亦第 4 例に於て去勢婦人に笳肉内，静脈内及で 経口的に投与してP.G.排浛量を追求してみた。総排浛量は測定し得なかつたが，実駼篹用内に於ては投与

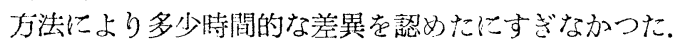

(3) Smith \& Smith ${ }^{51)}$ 仙中毒症及び糖尿病娃婦に於ける尿中P.G.の減少は，適当の estrogen を投与-する ことによつて增加せしめ得ると云い，Venning 攻び Browne ${ }^{522}$ は子宮発育不全症患者に estrogen を与える と prog.のP.G.への転化は增加すると報告し，Cope ${ }^{39}$ は続発性無月経でこれを認めてい.る.然るにMarrian

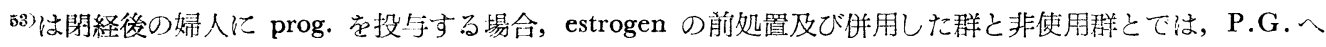
の転化の比率に著明な差異を喼めなかつたといつている。本実験の第 5,6 例に於ては直接てれを究明し得 なかつたが，BBTも2 相性を示さず，P.G.量も第 2,4例に比して明かに增量したとは云い難い，乙れに 
㥙個人差或はSmith \& Smith が Marrian の実験に関して指摘した如人, estrogen 及び prog. の両ホルモン 閂の比率乃至投与量偟因があるのかも知れない.

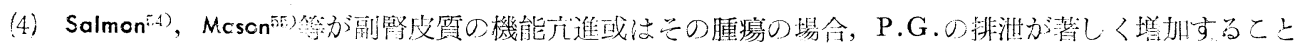

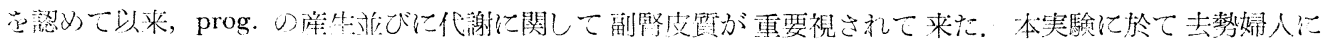

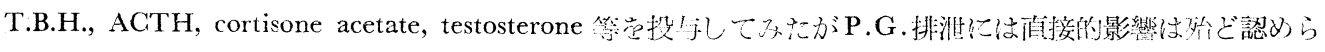
れなかつた。をこで下捶体一副掔皮質機能の正常な状態に於ける prog. と gonadotropin 或は corticoids と

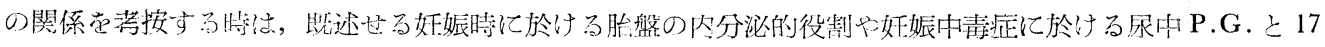

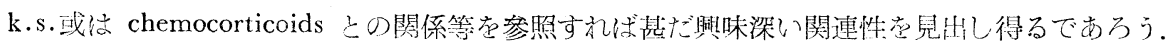

\section{第 5 章＼cjkstart全篇の総括涉に結論}

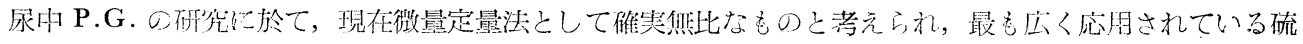

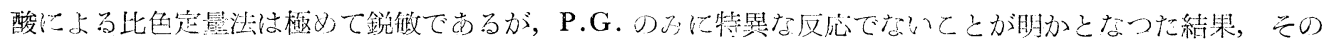

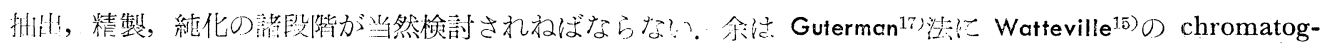

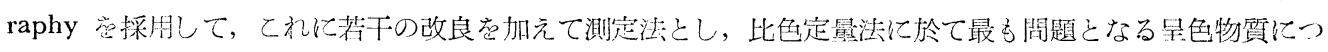

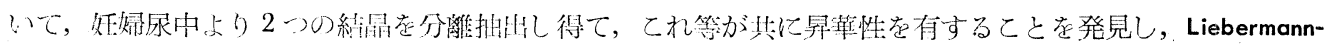

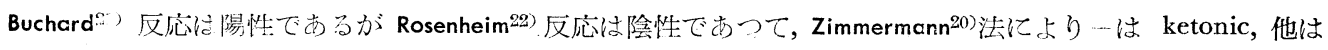

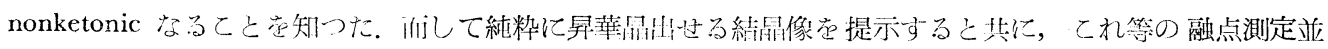

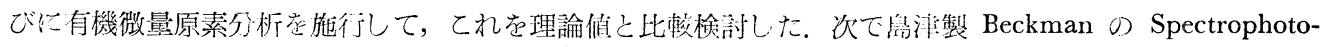
meter DU 型亘用いて比色定量に必要な Standard curve 克作成すると共に Cholesterol 及び Dehydroiso-

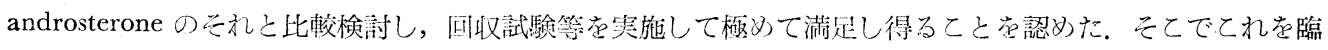
床的に応朋して，結論として大略次の如き成績を得艺。

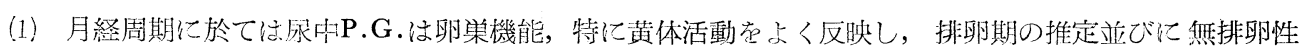

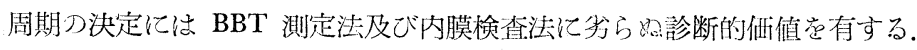

(2）：T.B.H. 危使胕して月経を人工的に移動せしもた場合，卵胞期に投与した㭙は極めて早期には尿中に P.G.は認放々れないが，黄体期に投与した場合は黄体期の延長と共に尿中P.G.量も幾分增量する。

(3) 黑常月経周期乃至機能的不娃症の治療に際して, T.B.H. 㹥他の一般ホルモン療法に比して, 上くP.G. の㴔最を促し，従つて卵巣機能を高めるものであると思考される。

(4) 正常奸娠の早期に於ける辰中P.G.量は黄体期のそれと著明な差異を示さないが, 第16週以後急速に増

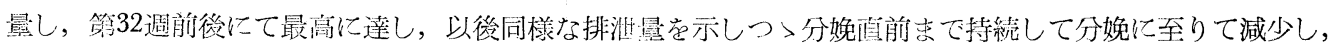

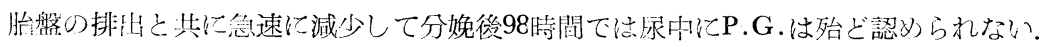

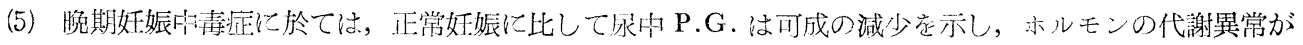

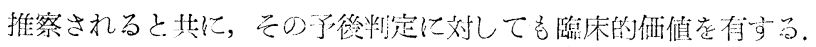

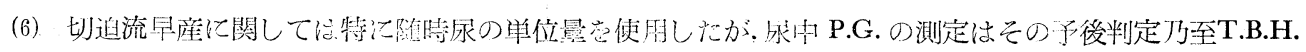
の刘果判定に対して充分役け。.

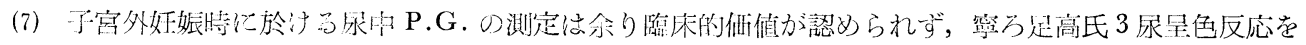

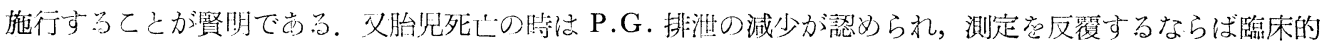
価值学有する。

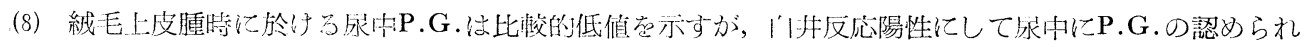

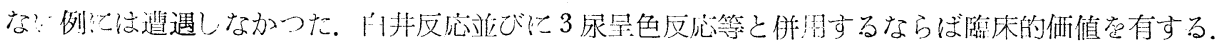

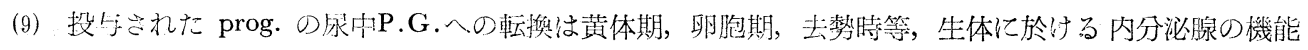
状態によつて差異がある。

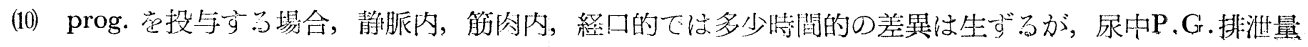
に著明な差異は認められない。 
(11) prog. を投与する場合，estrogen で前処嗔した場合としない場合とで，尿中 P.G. 排泄量には明かな 差異は認められない.

(12) 去勢婦人に T.B.H., ACTH, Cortisone acetate, Testosterone propionate 常投与しても尿中 P.G.排

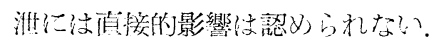

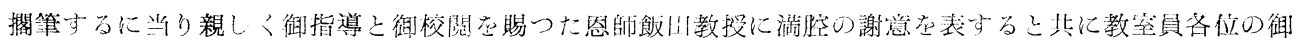

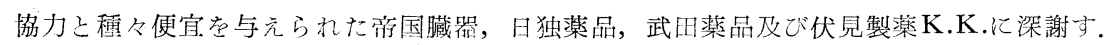

久本研究費の一部は昭和30年度文部省科学助成研究補助金に負つた。茲に列記して謝意を表する。

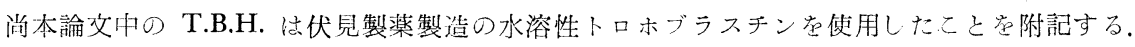

\section{文献}

1) Marrian: Biochem. J. 23, 1090, 1929.

2) Butenandt: Zeitschr. phys. Chem. 19, 140, 1930.

Butenandt et al: Ber. dtsch. Chem. Ges. 64, 1901, 1934.

4) Venning, Browne: Proc. Soc. Ex. Biol.

\& Med. 34, 792, 1936.

docrinology 6, 192, 1949 .

Biol. Chem. 126, 595, 1938.
5.) Plotz, Darup: Arch. Gynäk. 177. 486, 1950.

7) 藤井: 産婦の世界, 4, 1019, 1052.

9) Westphal, Buxton: Proc. Soc. Ex. Biol. \& Med. 42, 749, 1939.
6) Tompsett: En8. Verning, Browne: J.

Astwood, Jones: J. Biol. Chem. 137, 397, 1941. 11: Allen, Viergiver: J. Biol. Chem. 141, 837, 1941 12) 松田: 日産婦, 5, 31, 1953 . Biochem. J. 41, 609, 1947. 13) Parks, Mack: J. Clin. Endo. 7, 351, 1947.

14) Huber: al.: J. Clin. Endo. 1, 668, 1941. 15Watteville et al.: J. Clin. Endo. 8, 982, 1948.

16) Talbot et 17) Guterman et al.: J. Lab. \& Clin. Med. 33, 356, 1948. 18) Semmons et al.: J. Clin. Endo. 9, 853, 1949. 19; Smith: J. Clin. Endo. 10, 496, 1950. 20) Zimmermann: Zeitschr• Phys. Chem. 233, 257, $1935 . \quad$ 21) Liebermann, Buchard: Ber. 14, $1804,1885$. 22) Rosenheim: Ber. 72, 1224, 1939. 23) 锂石: 日産婦, 5, 359, 1953. 24; Davis, Fugo: Proc. Soc. Ex. Biol. \&Med. 66, 39, 1947. 25) Venning, Browne: Endocrinology 21, 711, 1937. Sommerville, Marricn: Biochem. J. 46, 285, 1950. 27: Rogers, Sturgis: J. Clin. Endo. 10, 89‘ 1950. 28. Hoffmann et al: Zbl. Gynäk. 67, 1082, 1943. 29; Buxton, Engle: Am. J. Obst. \& Gyn. Sep. 1950. 30: Mack et al: J. Clin. Endo. 9, No.1, 1949. 31) Hamblen: Am. J. Obst. \& Gyn. 44, 442, 1942. $\quad 32$ ) Kaufmans, Westphal: Arch. Gynäk. 179, 247, $1951 . \quad 33$; Porłes: Ann. d'Endo. 2, 215, 1941. 34) Jones et al.: Bull Jones Hopkins 75, 359, 1944 (Mauzey より). 35) Muzey: Am. J. Obst. \& Gyn. 50, 626, 1950. 37) Venning et al.: A.S. Physiology 123, 26, 1938 36; Llusia: Surgery Gyn. \& Obst. 89, 180, 1949. 38) 前山: 日産媂, 5, 1243, 1953. Cope: Brit. Med. Jour. 2, 545, 1940. 40) Hughes, Lloyd et al: J. Glin. Invest. 31, 1056, 1952. 41) 赤須: 日産婦, 655, 7, 1955. 42) 足高: 日産㖊, $547,6,1954$. 43) Guterman et al.: Am. J. Obst. \& Gyn. 58, 495, 1949. 44: 白井: 近畿産婦, 11, 34, 1928.4 45) Pigeaurd。 Burthiault: J. Obst. \& Gyn. Brit. Emp., LIX.4, 580, 1952 46) Stimmel et al.: J. Clin. Endo. \& Metab. 12, 371, 1952. 47) Buxton: Am. J. Obst. \& Gyn. 40, 202, 1940.48 ) Hamblen et al.: Endocrinology 27, 169, 1940. $\quad 49)$ Dorfman et al. : 'Endocrinology 42, 77, 1948. 50) Fischer, Colgan: J. Clin. Endocrin. \& Metab. 13, 1043, 1953 51) Smith \& Smith: Am. J. Obst. \& Gyn. 39, 405. 1940. 52) Venning, Browne: Am. J. Physiol. 123, 545, 1940. 53) Marrian: Recent Progress in Hormone Res. Vol. IV. P3, $1948 . \quad 54$ ) Salmon: Proc. Soc. Exper. Biol. \& Med. 47, 279, 1941. 55) Mason, Hoffman : Endocrinology 37, 111, 1945. 56; 飯田：日産婦, 3，199，1951. 57; 石塚：日産婦，4，140，1952. 58; 三宅：最新医， 8, 1, 1953. 59) 新延：産婦门世界， 4，129，1952. 60，小林：日産婦， 8，475，1956. 媂の世界，2，187，1950. 62: 飯田：应婦の世界，4，134，1952。 中四国誌，4,1, 1955. 64) 安井: 産婦の実際，3，712，1954. 275, 1950。6 66) 足高：木と臨床，1，391，1953. 